NBER WORKING PAPER SERIES

\title{
AGGREGATE PRICE SHOCKS AND FINANCIAL STABILITY: \\ THE UNITED KINGDOM 1796-1999
}

\author{
Michael D. Bordo \\ Michael J. Dueker \\ David C. Wheelock \\ Working Paper 8583 \\ http://www.nber.org/papers/w8583 \\ NATIONAL BUREAU OF ECONOMIC RESEARCH \\ 1050 Massachusetts Avenue \\ Cambridge, MA 02138 \\ November 2001
}

The authors thank Forrest Capie, Harold James and Anna Schwartz for comments, and Heidi Beyer for research assistance. The views expressed herein are those of the authors and not necessarily those of the National Bureau of Economic Research.

(C) 2001 by Michael D. Bordo, Michael J. Dueker and David C. Wheelock. All rights reserved. Short sections of text, not to exceed two paragraphs, may be quoted without explicit permission provided that full credit, including (C) notice, is given to the source. 
Aggregate Price Shocks and Financial Stability:

The United Kingdom 1796-1999

Michael D. Bordo, Michael J. Dueker and David C. Wheelock

NBER Working Paper No. 8583

November 2001

JEL No. E31, E52, C25, N13, N4

\begin{abstract}
This paper investigates the impact historically of aggregate price shocks on financial stability in the United Kingdom. We construct an annual index of U.K. financial conditions for 1790-1999 and use a dynamic probit model to estimate the effect of aggregate price shocks on the index. We find that price level shocks contributed significantly to financial instability during 1820-1931, and that inflation rate shocks contributed to instability during 1972-99. Both the nature of aggregate price shocks and their impact depend on the existing monetary and financial regime, but price shocks historically have been a source of financial instability.
\end{abstract}

Michael D. Bordo

Department of Economics

Rutgers University

New Jersey Hall

New Brunswick, NJ 08903

and NBER

bordo@economics.rutgers.edu
Michael J. Dueker

Research Department

Federal Reserve Bank of St. Louis

P.O. Box 442

St. Louis, MO 63166-0442

michael.j.dueker@stls.frb.org
David C. Wheelock

Research Department

Federal Reserve Bank of St. Louis

P.O. Box 442

St. Louis, MO 63166-0442

david.c.wheelock@stls.frb.org 


\section{Introduction}

The paramount monetary policy objective of the European Central Bank, as required by the Maastricht Treaty, is control of inflation. Several countries also have made inflation control the primary goal of monetary policy, and the central banks of many countries, including the United Kingdom but not the United States, set explicit inflation targets. This emphasis reflects a desire to avoid high and highly variable inflation that characterized the economies of many countries in the 1970s and 1980s.

Inflation and inflation variability impose a variety of costs on society. Many economists argue that by disrupting financial markets, inflation can exacerbate business cycles or reduce economic growth. Fisher $(1932,1933)$ was an early proponent of the view that price level movement is an important cause of business cycles through its effect on the real cost of debt. Schwartz $(1995,1997)$ picks up this theme, arguing that unanticipated shifts from inflationary to disinflationary monetary policy have been an important cause of increases in loan default rates and other forms of financial distress historically. Bernanke and Gertler (1989) and Bernanke, Gertler and Gilchrist (1999) argue that aggregate price instability can interact with information asymmetries and other frictions in credit markets to exacerbate business cycles. The lesson for monetary policy, Bernanke and Gertler (1999) conclude, is that "central banks should view price stability and financial stability as highly complementary and mutually consistent objectives.”"

This paper presents empirical evidence for the claim that price stability and financial stability are complementary by investigating the impact historically of aggregate price disturbances on financial stability in the United Kingdom. The U.K. is a useful case study because its long financial history provides the opportunity to study the relationship between aggregate price and financial conditions across multiple monetary and financial regimes.

\footnotetext{
1 Other studies conclude that credit market frictions can cause high inflation or inflation variability to depress economic growth. Choi, et. al. (1996), for example, argue that by lowering the real cost of borrowing, high inflation can lead to adverse selection, higher default rates, credit rationing and a reduction in the supply of investment capital, causing lower long-run growth.
} 
Moreover, reasonably consistent time series data exist on the U.K. price level, output, and monetary aggregates. Still, as with all countries, long time series data on loan default rates, household and business failure rates, and similar measures of financial conditions that are the focus of this study are scarce before the 1920s. Thus, to characterize aggregate financial conditions in the U.K. over time, we turn to narrative histories, along with various fragmentary data, to construct an annual index of financial conditions from 1790 to 1925 . We extend the index forward through the end of the $20^{\text {th }}$ Century using data on personal and corporate bankruptcy rates and on asset prices.

In combining narrative and quantitative sources to form a discrete index of financial conditions, our approach is similar to that often used to study banking and currency crises (e.g., Kaminsky and Reinhart, 1999; Bordo, et. al., 2001). Crises are sudden, dramatic events that sometimes mark the beginning of a prolonged period of financial distress. Our interest here lies with gauging the impact of aggregate price disturbances on the net worth of borrowers, rather than in identifying the determinants of crises. However, a discrete index of financial conditions also facilitates our study.

We use our index as the dependent variable in econometric analysis of the impact of aggregate price shocks on financial conditions. Because the annual index takes discrete values, we estimate a dynamic probit model that accommodates time series features of the data. We control for changes in real output, terms of trade, liquidity, and monetary regime, and investigate whether the impact of price shocks was affected by regulation of the financial sector. We find that aggregate price shocks have been an important cause of financial instability in the United Kingdom historically, except when war-related shocks were dominant or heavy financial regulation muffled the impact of macroeconomic disturbances on the financial sector.

Section II describes briefly how aggregate price shocks can disrupt financial conditions. Section III presents our index of financial conditions. Section IV describes the history of financial instability in the United Kingdom over our sample period and compares the index with 
various quantitative measures of financial conditions. Section V describes our econometric model and Section VI presents estimation results. Section VII concludes.

\section{Aggregate Price Shocks and Financial Instability}

Financial instability can be either a cause or a consequence of general macroeconomic instability. Banking panics, for example, were a principal source of monetary contraction, deflation, and declines in real economic activity in the United Kingdom before the mid- $19^{\text {th }}$ Century, and even later in the United States and other countries (Friedman and Schwartz, 1963; Bernanke, 1983; Bernanke and James, 1991). Macroeconomic shocks, such as a falling price level (or inflation rate) can, however, also be a source of financial distress. Because debt contracts typically are written in nominal, fixed rate terms, a decline in the price level increases the real cost of servicing outstanding debt, which can increase loan defaults and bankruptcies, and in turn put pressure on lenders. Even a decline in the rate of inflation can cause distress if the decline is unexpected and not hedged, because some borrowers will have insufficient revenue to service debt that could have been repaid in the absence of disinflation.

Fisher $(1932,1933)$ was among the first to describe the impact of a falling price level on financial conditions in a business cycle framework. According to Fisher, business cycle upturns are triggered by exogenous factors that provide new, profitable opportunities in key sectors of the economy. Rising prices and profits encourage more investment and also speculation for capital gains. Debt finance through bank loans increases deposits and the money supply, and raises the price level. A general optimism or euphoria takes hold, which increases monetary velocity and further fuels the expansion, while rising prices encourage further borrowing by reducing the real value of outstanding debt.

The process continues until a general state of "overindebtedness" is reached, that is, the point at which individuals, firms, and banks generate insufficient cash flow to service their liabilities. At this point, any shortfall in the price level from its expected value, regardless of cause, will leave borrowers unable to service their debts and lead to distress selling. As loans are 
extinguished, bank deposits and the money supply decline, further lowering the price level. Deflation increases the real burden of remaining debt, leading to further bankruptcies and declining economic activity - a process referred to as "debt-deflation." The process continues until either widespread bankruptcy has eliminated the overindebtedness or a reflationary monetary policy has been adopted. Once recovery begins, however, the whole process will repeat itself. $^{2}$

Schwartz $(1988,1995,1997)$ offers an alternative explanation, focused explicitly on monetary policy, of how aggregate price instability can lead to financial instability. Schwartz contends that when monetary policy produces fluctuations in the inflation rate, information problems associated with evaluating alternative investments are made worse which, in turn, increases financial instability:

Both [borrowers and lenders] evaluate the prospects of projects by extrapolating the prevailing price level or inflation rate. Borrowers default on loans not because they have misled uninformed lenders but because, subsequent to the initiation of the project, authorities have altered monetary policy in a contractionary direction. The original price level and inflation rate assumptions are no longer valid. The change in monetary policy makes rate-of-return calculations on the yield of projects, based on the initial price assumptions of both lenders and borrowers, unrealizable. (Schwartz 1995, p. 24)

Schwartz does not model formally how changes in the inflation rate can lead to financial instability, but her description fits well with the "monetary misperceptions" model of Lucas $(1972,1973)$. In that model, individuals are unable to distinguish with certainty shifts in relative prices from changes in the aggregate price level. This uncertainty can lead to resource misallocation, which is corrected only once the true nature of a price change becomes known.

This model is easily extended to incorporate financial decisions. Uncertainty about the nature of price changes can lead to bad forecasts of real returns to investment projects and, hence, to unprofitable borrowing and lending decisions. Such mistakes can affect borrower defaults ex post. An unanticipated disinflation, for example, can increase default rates by causing realized borrower incomes to fall below expectations. Although disinflation causes the real income to

2 See Capie and Wood (2001) for further discuss of Fisher's theory and a comparison with that of Keynes. 
lenders on loans that do not default to exceed expectations, an increase in default rates could more than offset this gain and result in significant distress for lenders. In the aggregate, financial instability is likely to be associated with disinflation because some projects will generate insufficient income to repay loans unless the rate of inflation equals or exceeds the rate that had been expected when the loans were made.

Higher than anticipated inflation, by contrast, can cause financial exuberance. Lending booms can result if positive aggregate price disturbances cause borrowers and lenders to form optimistic expectations about future real returns to projects because of their inability to distinguish shifts in relative prices from changes in the aggregate price level. Such financial exuberance can last only until the true path of aggregate prices is realized.

Bernanke and Gertler (1989) and Bernanke, et. al. (1999) extend the analysis further by considering the implications of aggregate price shocks in the presence of credit market frictions. Asymmetric information between borrowers and lenders, for example, will cause a decline in borrower net worth to drive up agency costs and, hence, the cost of external finance. Thus, by eroding the net worth of borrowers, unanticipated deflation will increase the cost of external finance and thereby exacerbate swings in borrowing and, hence, in investment, spending and output.

\section{An Index of U.K. Financial Conditions}

We investigate empirically the impact of aggregate price shocks on U.K. financial conditions historically to provide evidence on the extent to which price stability and financial stability are complementary. In lieu of consistent, continuous data on loan default rates, bank and firm profit rates, returns on fixed assets, and similar aspects of financial condition, we use various narrative and quantitative information to develop a comprehensive annual index of U.K. financial conditions for 1790-1999.

Our index assigns each year from 1790 to 1999 to one of five categories: "severe financial distress," "moderate distress," "normal," "financial expansion," or "financial euphoria," 
as reported in Table 1. For 1790-1925, our principal source is the compilation of annual summaries of economic and financial conditions produced for several countries by Willard Thorp (1926) in a volume for the National Bureau of Economic Research. We compare the classifications based on Thorp's summaries with available data on banking conditions, and firm and household bankruptcies to gauge the reasonableness of our index. Although Thorp's (1926) summaries end with 1925, more quantitative information on financial conditions is available for the period since then. For 1926-99, we construct a five-category index from annual time series on bankruptcies and corporate insolvencies, and asset prices.

Thorp's (1926) annual summaries include information about prices, foreign trade, employment, and notable political events, as well as about financial and monetary conditions. In using these summaries to derive our index, we focus exclusively on Thorp's descriptions of financial and monetary conditions. We give several examples below illustrating the mapping of Thorp's descriptions into specific index categories.

We assign years that Thorp notes had "many failures," bank runs or panics, "tight" monetary conditions, or sharp declines in asset prices, to the "severe distress" category. To the "moderate distress" category, we assign years that Thorp describes in less strong terms. Such years also might have had severe financial panics or distress during a portion of the year, but normal or financially expansionary conditions in a significant part of the year. One such year was 1825, when rapid financial and economic expansion during the first part of the year was followed by severe distress marked by a stock market crash in May and banking panic in December (Neal, 1998). We are interested in capturing the mean state of financial conditions during the year, rather than simply identifying the occurrence of a crisis, as typically is done in studies of the determinants or effects of crises (e.g., Kaminsky and Reinhart, 1999; Bordo, et. al., 2001). Hence, we classify 1825 as a year of "moderate" financial distress, weighting implicitly the expansionary conditions of the first one-third of the year with the severely distressed conditions of the year's latter two-thirds. 
Based on Thorp's descriptions, we also classify some years as having unusually expansionary or euphoric financial conditions. Such years tended to have below normal business failure rates and above normal increases in asset prices. Thorp describes several years as having “active speculation," "easy money," “many new companies," "large profits," etc. We classify such years as having "expansionary" financial conditions. Thorp characterizes financial conditions in a few years in especially glowing terms. For example, in 1809 he reports a "frenzied" pace of speculation. In 1836, he writes that there was "excited" speculation in stocks and "active formation of joint stock companies, especially banks." And, in 1919 there was "rapid industrial expansion" and a "rapid rise in stocks," with "boom" conditions generally. We classify all three years as ones of financial "euphoria."

For 1925-99, we construct our index from data on personal and commercial bankruptcies, and the excess return to housing investment. Financial distress is characterized by elevated rates of personal and firm bankruptcy, as households and firms find it increasingly difficult to repay existing loans and borrow additional funds. Similarly, years of unusually expansionary financial conditions are characterized by low rates of failure. Modern U.K. bankruptcy law dates from an act of 1883 . The act was revised in 1914 and again in 1976, but provided a fairly consistent set of bankruptcy rules and procedures until 1986, when a new bankruptcy law took effect. The new act simplified the process of declaring bankruptcy and introduced a number of other changes that preclude a meaningful comparison of bankruptcy rates before and after $1986 .^{3}$ Reasonably consistent data on corporate insolvency rates are, however, available from 1960 to the present. Thus, in constructing our index, we use the rate of household and unincorporated firm bankruptcy (bankruptcies per capita) for 1926-59 and the rate of corporate insolvency (insolvencies divided by number of firms) for 1960-99 as one component of our quantitative index.

In addition to household and firm failures, episodes of financial distress or expansion can be reflected in the movement of asset prices. Periods of financial expansion, easy monetary 
conditions, lending booms and high confidence levels are often characterized by relatively high returns on risky assets, such as real estate. Relatively low returns on such assets, on the other hand, can indicate financial distress as lenders redirect their investment to safe assets. We use the excess return on housing, measured as the annual percentage increase in an index of U.K. housing prices less the annual average market yield on consols, as an index component. Because real estate purchases are often debt financed, a shock to real estate prices directly affects the net worth of borrowers - the aspect of financial conditions we are primarily interested in capturing. ${ }^{4}$

We construct our index of financial conditions for 1926-99 by computing annual deviations of the bankruptcy (insolvency) rate and excess housing returns series from their trends. We then average the two series of deviations so that years of financial distress, for example, were characterized by high rates of bankruptcy (insolvency) and/or low excess returns to housing. In averaging, we assign less weight to the more volatile series during subperiods of interest. Finally, we assign each year to one of five categories of financial conditions based on this average deviation measure. Full details on construction of the index are presented in Appendix A. We do not compute an index for 1940-47 because of the unusual economic conditions in Britain during and immediately after World War II, and we treat those years separately in our empirical analysis.

\section{A History of Financial Instability}

Before examining the relationship between aggregate price shocks and financial conditions, as reflected by our index, we briefly compare the index with information on bank failures and bankruptcies that exist for parts of the period covered by our index. We assign index categories from 1 for "severe distress" to 5 for "financial euphoria. Figure 1 plots annual values

3 See "Bankruptcy: A Fresh Start," Department of Trade and Industry (www.insolvency.gov.uk).

${ }^{4}$ We considered and rejected using the return on equities as a component of our index. Equity purchases tend not to be highly leveraged, and so shocks to equity prices less directly affect the financial condition of borrowers and lenders. Moreover, consistent series on equity prices are not available throughout the period of interest, and capital market issues were heavily regulated after World War II. We also rejected measures of banking conditions. Bank profits data are available for only a portion of the period of study, and during much of that period profit rates were influenced by mergers, market structure and implicit regulation which distorted their relationship to macroeconomic disturbances (see Capie, 1988; Dow, 1964; Wadsworth, 1973). 
of our index alongside the number of country bank failures, which are available for 1791-1830. Figure 2 plots the index and bankruptcies per capita for 1801-52. ${ }^{5}$ Years we classify as having moderate or severe financial distress based on Thorp (1926) tended to have above average numbers of bank failures and bankruptcy rates, e.g., 1793, 1810, 1814-16, 1825-26. Years we classify as having unusually expansionary or euphoric financial conditions, by contrast, tended to have low numbers of bank failures and low bankruptcy rates, e.g., 1802, 1808-09, 1823-24, and 1834-36.

The most prolonged period of financial distress in the United Kingdom during the $19^{\text {th }}$ century occurred during $1837-43$. The crisis of 1837 was preceded by a sharp increase in commodity prices and a stock market boom (Temin 1969; Levy-Leboyer, 1978). The Bank of England raised Bank Rate in the fall of 1836 to halt an external drain, which quickly ended the boom, initiated a decline in the price level and led to panic and recession. Thorp (1926, p. 160) describes 1837 as a year having "many failures, ... continued financial strain [and] panic." Easy monetary conditions in 1838 were followed by "severe" tightening in 1839, along with "many failures" and a "gold crisis." 1840 brought "signs of improvement" early in the year that proved short-lived, whereas the severe depression of 1841 was characterized by tight money and again "many failures." After having fallen to low levels during 1833-36, bankruptcy rates increased sharply in 1837 and again in 1840-42, though not to the levels observed during the distress years of $1810-11,1815-16$, and 1826 .

Financial distress moderated during the mid-1840s. Financial speculation "revived" in 1844 and was "active" in 1846, according to Thorp (1926), and equity prices soared while bankruptcy rates fell off. Severe financial distress, reflected in a sharp increase in bankruptcies, returned in 1847-48, but financial expansion resumed in the early 1850s. 1852, for example,

\footnotetext{
5 We thank Anna Schwartz for providing annual data on bank failures and bankruptcies, which were compiled during the preparation of Gayer, et. al. (1953).
} 
witnessed "very easy" monetary conditions and "considerable activity in forming new enterprises" (Thorp, 1926).

Although we lack data on either bankruptcies or bank failures from 1853 to the mid1880 s, our index reflects the well known financial history of the period. For example, "severe distress" returned in 1857, when financial panic originating in the United States spread to the United Kingdom through correspondent banks in Liverpool. Financial conditions improved in 1858, but remained "moderately" distressed.

The cycle of boom and bust was repeated again in the 1860s, with a period of prosperity, rising prices and stock market speculation culminating in a banking panic in 1866 when the Bank of England raised Bank Rate and Overend, Gurney and Company, a major discount house, collapsed (Batchelor, 1986). Thorp (1926) cites "many failures," "panic," and the collapse of security speculation as the major financial disruptions of the year, and we classify the year as one of "severe" distress. Financial conditions remained "moderately" distressed in 1867-68.

$1867-1913$

Figure 3 compares our index against the annual percent change in the bankruptcy rate for 1885-1913. The U.K. enacted its first comprehensive bankruptcy law in 1883, and bankruptcy rates were high for a few years thereafter. Beginning about 1890, however, years classified by our index as having financial distress generally coincide with increases in bankruptcy rates. The bankruptcy rate increased sharply in 1891, and remained high through 1894, a period of financial distress according to our index. By contrast, the bankruptcy rate declined in 1899 and 1906 , when our index indicates that financial conditions were expansionary.

\section{World War I to 1999}

The end of World War I brought a financial "boom" in 1919, according to Thorp (1926), but this "feverish activity" soon gave way to tight monetary conditions, a halt to the growth of bank lending and deflation. After a year of severe financial distress in 1921, financial conditions 
stabilized somewhat, but tight monetary conditions and chronic gold reserve losses plagued the U.K. economy for ten more years, culminating in suspension of convertibility in September 1931.

Beginning in 1926, our index of financial conditions is based on the bankruptcy/insolvency rate and the excess return on housing, as described above. Figures 4 and 5 plot our index and the data that underlay it for 1926-99 (excluding 1940-47). ${ }^{6}$ Years of moderate or severe financial distress correspond to years that had unusually high bankruptcy (or insolvency) rates and low excess real estate returns. Years of financial expansion, by contrast, generally had low bankruptcy (or insolvency) rates and high excess returns.

Although the U.K. suffered relatively less financial distress during the Great Depression than many other countries, 1931 and 1932 were years of moderate distress, as reflected in high rates of bankruptcy and stagnant housing prices. 1934, 1936, and 1939, by contrast had expansionary financial conditions, reflecting unusually high excess housing returns and low bankruptcy rates.

Our index resumes in 1948 when, under the influence of heavy regulation, the U.K. financial system had entered a period of stability. Sharp increases in excess housing returns in 1957-58 account for modest financial expansion in those years.

The U.K. financial sector came under increasing strain during the 1960s, reflected primarily in an increase in corporate insolvency rates, but also low returns on fixed assets, including housing. Sharp increases in asset prices soon followed, however, and real estate price spikes in 1973 and 1975 cause our index to classify financial conditions in both years as moderately expansionary, despite an increase in bankruptcies in $1975 .^{7}$ Boom conditions

\footnotetext{
${ }^{6}$ The annual data plotted for the bankruptcy/insolvency rate and the excess return on housing are standardized deviations from the de-trended mean of each series, as described above and in Appendix A.

7 The U.K. stock market declined precipitously in 1974 and in terms of share prices, the mid-1970s was a period of considerable financial instability. Corporate insolvency rates and returns to housing investment were not unusual in 1974, however, and, hence, our index classifies the year as having had "normal" financial conditions. In addition to being a less direct indicator of the condition of borrowers, as noted in footnote 4, we do not include the return on stocks in our index in part because of the extreme volatility of U.K. share prices in the postwar era and the different regulatory controls imposed on the stock market in this period (see Dow, 1964).
} 
returned at the end of the decade. Low rates of bankruptcy and rapid growth in real estate prices occurred at the inflation and cycle peak in 1979, producing a "euphoric" year on our index, which carried over into 1980 before a switch to tight monetary policy took hold. The disinflation of the early 1980s, however, was accompanied by falling excess returns on real estate and other assets, and with high household and business failure rates that lasted for several years.

Bank lending grew rapidly in the 1980s and household and firm debt growth accelerated. Real estate and other asset prices began to increase sharply in the late 1980s to 1989, which our index classifies as a year of moderate expansion.

The boom of the late 1980s ended with the recession of 1989-92, which saw a marked increase in firm insolvency rates and low excess returns on risky assets, such as real estate. Although we adjust for the increased variability of the insolvency rate over time in constructing our index, as described in detail in Appendix A, insolvencies reached such a high level in 1993 that our index classifies the year as one of severe financial distress.

\section{Empirical Analysis: The Model}

We use our index of financial conditions as the dependent variable in an econometric analysis of the impact of aggregate price shocks on U.K. financial conditions historically. Because the index is categorical, we use a probit model, modified to account for time series features of the data. The general set-up is that an observed variable, $y$, takes on one of $J$ different discrete values. A continuous latent level, $y^{*}$, follows a standard time series process and determines the discrete level of $y$. The mapping between the continuous latent variable and the

discrete variable is $y_{t} \in$ category $j$ if $y_{t}^{*} \in\left(c_{j-1}, c_{j}\right)$, where $c$ is a vector of cut-off parameters that determine the boundaries of the categories.

A basic time-series probit model of $y^{*}$ includes at least one autoregressive term on the right-hand side of the equation for the latent variable:

$$
y_{t}^{*}=\rho y_{t-1}^{*}+\mathrm{X}_{t} \beta+\varepsilon_{t}
$$


Eichengreen, et. al. (1985) estimate such a model using maximum-likelihood procedures that require numerical evaluation of an integral for each observation in order to obtain the density, $h$, of $y_{t}^{*}$, where $\phi$ is the standard normal density and $I_{t}$ is the information available up to time $t$ :

$$
h\left(y_{t}^{*} \mid I_{t}\right)=1 / \sigma_{\varepsilon} \int_{l_{t-1}}^{U_{t-1}} \phi\left(y_{t}^{*} \mid \sigma_{\varepsilon}\right) h\left(y_{t-1}^{*} \mid I_{t}\right) d y_{t-1}^{*},
$$

where $\left\{l_{t}, U_{t}\right\}=\left\{c_{j-1}, c_{j}\right\}$ if $y_{t} \in c a t . j$. Because numerical evaluation of these integrals is time-consuming and approximate, it is not tractable under direct maximum-likelihood estimation to extend the model to include additional features, such as regime-switching parameters.

By contrast, we use Gibbs sampling to estimate equation (1) and allow for possible regime switching. Gibbs sampling offers a tractable method of estimating the dynamic probit model, as well as other models where the joint density of $y_{t}^{*}$ and $y_{t-1}^{*}$ is difficult to evaluate (see Dueker 1999). Gibbs sampling involves generating a sample of draws from a joint distribution through a sequence of draws from the respective conditional distributions. In the present context, such data augmentation allows one to treat augmented values of $y_{s}^{*}, s \neq t$, as observed data when evaluating the conditional density of $y_{t}^{*}$. Thus, one conditions the density of $y_{t}^{*}$ on a value, instead of a density, of $y_{t-1}^{*}$, making the problem much simpler than recursive evaluation of the integral in equation (2). Furthermore, once the latent variable has been augmented, it becomes straightforward to model any regime switching, such as conditional heteroscedasticity. Appendix C presents details and estimates of regime switching in our dynamic ordered probit.

\section{Independent Variables}

In accordance with the discussion in Section II, we expect that negative aggregate price shocks increase financial distress, whereas positive shocks reduce financial distress and move financial conditions toward expansion and euphoria. For 1795-1931, we identify aggregate price shocks in terms of unanticipated movements in the price level $\left(\mathrm{P}^{*}\right)$. Under the prevailing gold standard regime of this era, the price level exhibited a stochastic trend and was generally mean 
reverting, reflecting changes in the supply and demand for gold (Bordo and Schwartz, 1999). The United Kingdom permanently abandoned the gold standard in September 1931, and the U.K.

price level has increased almost continuously since then. Hence, for 1932-99, we identify shocks in terms of unanticipated changes in the inflation rate $(\pi *){ }^{8}$

In addition to aggregate price shocks, our econometric model controls for other possible sources of financial instability, including fluctuations in real output, liquidity and the terms of trade. We expect that financial conditions also move away from distress toward expansion as a result of increases in the growth rates of real output ( $\Delta \ln$ GDP), liquidity (high-powered money) ( $\Delta \ln$ Base), and terms of trade (export prices divided by import prices) ( $\Delta \ln$ TTrade). Complete descriptions and data sources are presented in Appendix B.

\section{Monetary and Financial Regimes}

We investigate empirically the impact of aggregate price shocks on U.K. financial conditions across different monetary and financial regimes. These regimes are important because they affect both the nature of price (inflation) expectations, the frequency and size of aggregate price shocks, and extent to which unanticipated changes in the price level (inflation rate) affect financial conditions.

Whereas the formation of price level and inflation rate expectations reflect the extant monetary regime, financial market structure and regulation can impinge on the relationship between macroeconomic disturbances and financial conditions. Government controls over bank lending and capital market issues, for example, can interfere with financial responses to market forces. Other government policies, such as flat-rate priced deposit insurance, can interact with macroeconomic disturbances to exacerbate financial distress. In the United States, for example,

\footnotetext{
8 We measure price shocks using autoregressions with exponential GARCH errors (Nelson, 1991). For 1795-1931, we estimate a second-order autoregressive model of the log of the price level with EGARCH(1,1) errors. For 1932-99, we estimate a first-order autoregressive model of the inflation rate with $\operatorname{EGARCH}(2,1)$ errors. To form the aggregate price shocks, we divide the model residuals by the conditional standard deviations, so that extremely volatile periods do not receive disproportionate weight in the probit model estimation.
} 
deposit insurance has been cited as encouraging depository institutions to take uneconomic risks that resulted in higher numbers of bank and thrift institution failures during the 1980s than otherwise might have occurred (e.g., Barth, 1991). Our econometric analysis allows for structural breaks in the relationship between aggregate price shocks and financial stability at major changes in financial regime.

Figures 6 and 7 plot December observations on the U.K. price level during 1790-1866 and 1867-1931 alongside our index of financial conditions. Figure 8 plots annual (DecemberDecember) inflation rates during 1932-99 alongside our index. ${ }^{9}$ The British pound was made fully convertible into gold in 1717 (Kindleberger 1984, pp. 57-60). Britain remained on the gold standard until September, 1931. With the exception of two extended periods in which convertibility was suspended, 1797-1820 and 1914-25, the U.K. price level exhibited little trend or variability, especially during the "classical" gold standard era from about 1867 to 1913. Hence, for 1795-1931, we identify aggregate price shocks in terms of changes in the price level $\left(\mathrm{P}^{\mathrm{ue}}\right)$. Although we consider the periods of wartime suspension to be part of the gold standard regime (Bordo and Kydland, 1995), our econometric analysis does allow for a structural break in the impact of aggregate price shocks on financial conditions at $1820 / 21 .^{10}$

We also test for a structural break at 1866/67. The variability of the price level declined after 1866, as more of the world became linked to the gold standard and as the Bank of England began to act as lender of last resort. The U.K. banking system also went through a period of consolidation that made it considerably more stable (Capie, 1995; Sheppard, 1971; Sykes, 1926). The period witnessed rapid growth of new financial intermediaries, such as discount houses,

\footnotetext{
9 We plot December observations of the Gayer, et. al. (1953, p. 468) index of wholesale prices of domestic and imported commodities for 1790-1844, linked to Klovland's (1993) "market price" commodity index for 1845-90, and the Sauerbeck-Statist commodity price index for 1891-1947. The inflation rate series for 1948-99 is based on December observations of the Retail Price Index. Alternative price indexes are available, but while their short-run fluctuations differ, all exhibit similar trends in the price level and inflation rate. In our econometric analysis, we report results for the series plotted in Figures 8-10, as well as for an annual average cost-of-living index.

10 We also isolate World War I (1914-18) in our econometric analysis using dummy variables.
} 
private banks, insurance companies and building societies, however, and the securities market remained active. Financial expansion in this period was reflected in the growth of new intermediaries and lending booms, while financial distress was reflected in the failures of such institutions and their borrowers.

The next fundamental change in monetary regime occurred in September 1931, when Britain left the gold standard following a massive loss of reserves (e.g., Eichengreen, 1992). Since then, the U.K. price level has increased almost continuously, and for 1932-99 we identify aggregate price shocks as unanticipated changes in the inflation rate $\left(\pi^{\mathrm{ue}}\right)$. We test for the possibility of a structural break at 1971/72, however, corresponding to the collapse of the Bretton Woods System, as well as the beginning of a sustained period of financial deregulation.

World War II brought heavy government control of the domestic financial system. Capital market issues, both foreign and domestic, were regulated by a Capital Issues Committee until 1959, when controls on domestic issues were relaxed, but those on foreign issues retained. Bank lending was not subject to formal controls after the war, though authorities effectively pressured banks to limit advances (Dow 1964, pp. 235-36).

Financial deregulation continued in the 1970s and accelerated in the 1980s. Ceilings on bank lending were eased during 1970-71, and exchange controls were removed in 1979. The 1980s saw the removal of controls on bank and building society lending, and deregulation of the stock exchange. It is our conjecture that free of the draconian controls of the first three post-war decades, U.K. financial conditions became more responsive to macroeconomic disturbances, including shocks to the inflation rate.

\section{Empirical Analysis: The Results}

We use two different price level series in our econometric analysis, and our results are sensitive to the choice. Using December price level observations of a commodity price index (retail price index for 1948-99), we find a stronger impact of price shocks on financial conditions than when we use an annual average cost-of-living index. The principal reason for this appears to 
do with the timing of financial panics and subsequent financial distress within years. Before the $20^{\text {th }}$ Century, financial panics often occurred at price level peaks, and prices usually declined sharply after the onset of panic. The price level at the end of a crisis year could be considerably lower than it was before the crisis occurred. Thus, annual changes in the price level measured using December observations often show a price level decline when changes measured using annual average observations do not. Because considerable financial distress often occurred in the wake of financial crises, we observe a closer correlation between financial distress and price level declines using December price level observations than using annual averages.

Results of our probit model estimation are presented in Table 2. In addition to coefficient estimates for each independent variable, we report 90 and 95 percent confidence interval estimates for each coefficient. When an interval does not include zero, the coefficient estimate is statistically significant at the corresponding significance level. ${ }^{11}$

We test for changes in the impact of aggregate price shocks on financial conditions across five periods: 1796-1820, 1821-66, 1867-1931, 1932-71, and 1972-99. Because of the unusual economic conditions of the two world wars, we isolate 1914-18 and 1940-49 using dummy variables. Using the December price index, the coefficient estimates on aggregate price shocks $\left(\mathrm{P}^{\mathrm{ue}}, \pi^{\mathrm{ue}}\right)$ are positive and statistically significant at 95 percent for $1821-66,1867-1931$, and $1972-$ 99, indicating that positive price level shocks move financial conditions away from distress toward expansion. Using the annual average cost-of-living index, aggregate price (inflation) shocks are significant only during 1972-99.

1796-1931

We find no evidence that price level shocks were an important cause of financial instability during 1796-1820. War-related shocks appear to have been a dominant cause of financial distress in these years. Of the three years of severe financial distress in this period, only 
1816 followed a prolonged period of deflation (see Figure 6). Financial distress in 1793 was associated with a banking panic triggered by the outbreak of war with France, and the Panic of 1797 was caused in part by fears of invasion. Episodes of "moderate" financial distress, such as those of 1799-1800 and 1811-12 apparently also were caused by war events, and were not closely related to large declines in the price level (Gayer, et. al., 1953).

During 1821-1931, by contrast, aggregate price shocks do appear to have contributed to financial instability. Further, we find no evidence of a change in the marginal impact of aggregate price shocks between 1821-66 and 1867-1931. As illustrated in Figures 6 and 7, however, the U.K. price level was considerably more stable during 1867-1913 than before 1866, as were financial conditions.

One measure of the economic impact of aggregate price shocks on financial conditions is the average size shock required to move financial conditions from one state to another. In standard probit estimation, the mean of the latent variable is not recovered. Because the Gibbs sampler used here provides inferred values (draws) of the latent variable, $y^{*}$, however, we can calculate $\beta \sigma_{x} / \sigma_{y^{*}}$ and $\bar{y}^{*} / \sigma_{y^{*}}$. The former indicates the immediate change in $y^{*} / \sigma_{y^{*}}$ caused by a one standard deviation size price shock ("impact effect"), and the latter indicates the average distance that $y^{*}$ lies from the boundary between the moderate distress and normal states (“average distance"). Here we normalize distances between categories of financial conditions by defining $y^{*}=0$ as the boundary between the normal and moderate distress states.

Based on model estimates using the December price index, for 1822-1866, the impact effect is 0.308 and the average distance is 0.260 . Thus, on average, a 0.84 standard deviation size negative price shock was necessary to cause financial conditions to deteriorate immediately from the average level (located in the middle of the normal state) to moderate distress, all else equal.

11 Because Gibbs sampling is a Bayesian monte carlo approach to estimation, it is standard practice to report the empirical confidence interval of the coefficients from the Gibbs iterations, rather than classical 
The dynamic probit also captures the long-run effects of changes in the explanatory variables.

With a coefficient of approximately 0.30 on the lagged dependent variable, the long-run impact of an aggregate price shock was roughly 1.43 times the initial impact. Hence, a 0.59 standard deviation size aggregate price shock is sufficient to move financial conditions from normal to the moderate distress state in the long-run.

As noted above, the impact of a given-sized price shock on financial conditions during 1867-1931 was similar to that of 1821-66, but the price level was more stable after 1866 . During 1867-1931, we estimate that a negative price shock of approximately 2.25 (1.57) standard deviations was required to produce immediate (long-run) deterioration in financial conditions from average to moderate distress (the impact effect is 0.192 and the average distance 0.432 ). Of course, a smaller shock could tip financial conditions from the bottom half of the normal range into moderate distress, and a simple counterfactual analysis indicates that deflationary shocks can account for financial conditions being in a state of "moderate distress" in $1875,1884,1885,1894$, and 1931 when they would have been "normal" had no shocks occurred in those years. In addition, a deflationary shock can explain why financial conditions were characterized by "severe distress," rather than "moderate distress," in $1878 .{ }^{12}$

Another indicator of the economic impact of aggregate price shocks is the contribution of such shocks to the probability that financial conditions are in a particular state. The marginal impact of an independent variable on the probability of being in a particular state is often evaluated at the mean of the data. Here, however, it is meaningful to calculate the marginal effect of aggregate price shocks at the boundary between the moderate distress and normal states, i.e., where $y^{*}=0$. At this point the probability that a random disturbance will tip financial conditions into a distress state is 0.50 . Moreover, evaluating the marginal effect at $y^{*}=0$ in each subperiod,

standard errors (see Chib, 1993).

${ }_{12}$ The counterfactual financial conditions index value for each year is determined by calculating the estimated value of the latent variable of the probit model under the assumption of no aggregate price shocks and comparing the latent variable estimate with the cut-off constants in Table C.1. 
rather than at subperiod specific mean values of $y^{*}$, facilitates comparison of the marginal effects across subperiods.

In our model, the probability of not being in one of the two states of financial distress is $1-\mathrm{F}\left(-\mathrm{X}_{t}^{\prime} \beta / \sigma_{t}\right)$, where $\mathrm{F}$ is the normal cumulative density function and $f$ is its derivative.

Hence, the marginal effect of a change in $\mathrm{X}$ at $y^{*}=0$ is:

$$
\frac{\partial \operatorname{Pr}(\text { nodistress })}{\partial x_{i}} \sigma_{x_{i}}=f\left(y^{*}=0\right) \beta_{i} \sigma_{x_{i}}
$$

The partial derivative is multiplied by the standard deviation of $x_{i}$ to reflect the size of the shocks. Assuming the normal density for $f$, the marginal impact effect is 0.17 for $1822-66$ and 0.12 for 1867-1931 (again based on estimates using December price observations), indicating that a one standard deviation size negative price shock would increase the probability of distress from 50 to 67 percent during $1822-1866$ and from 50 to 62 percent during $1867-1931 .^{13}$

Whereas aggregate price shocks contributed substantially to financial distress during 1821-1931, our probit model estimation detects only limited effects of real output growth, liquidity, and changes in the terms of trade on financial conditions. We find that growth in real GDP had a positive and statistically significant effect on financial conditions during 1830-1931, as did growth of high-powered money during 1832-1931. ${ }^{14}$ We detect, however, no statistically significant relationship between changes in the terms of trade and financial conditions over our estimation period.

1932-99

For the period 1932-1999, we investigate the possibility of a break in the impact of inflation rate shocks on financial conditions at 1971/72. For 1932-71, we detect no statistically

13 One caveat regarding these results is that with Markov switching the actual density is not normal but a mixture of normals. The distortion from using the normal density is not large, however. Details are available from the authors.

${ }^{14}$ We impose coefficient breaks for GDP in 1830 and for high-powered money in 1932 to reflect changes in data sources and variable definitions. 
significant impact of inflation shocks on financial conditions in our probit model estimation

(Table 2). Heavy regulation of bank lending, capital issuance, and other financial controls seem to have effectively insulated U.K. financial conditions from macroeconomic instability during this period. Of course, this stability may have come at the cost of restricted access of firms and households to credit, and limited opportunities for savers.

For the less-regulated era, 1972-99, financial conditions were more responsive to inflation rate shocks. Regardless whether we use the December or annual average values of the price level, inflation rate shocks have a statistically significant impact on financial conditions in our probit model. Positive shocks moved financial conditions away from distress toward expansion, while negative shocks increased financial distress. Based on December price observations, we estimate that a 1.93 standard deviation size negative inflation shock would produce an immediate deterioration of financial conditions from normal to moderate distress. In the long run, a 1.35 standard deviation size negative inflation shock would have the same effect. Further, we estimate that a one standard deviation size negative inflation shock would increase the probability of financial conditions being in a distress state from 50 to 70 percent.

The period 1972-99 was marked by high and highly variable inflation during the 1970s, and disinflation and prolonged financial distress during the early-to-mid-1980s. Inflation accelerated once again at the end of the 1980s, accompanied by a financial expansion, but inflation declined abruptly in the early 1990s and financial conditions deteriorated markedly, with especially high rates of corporate insolvency. Finally, the end of the 1990s brought a period of low, stable inflation and moderate financial expansion. The three decades of this most recent era seem clearly to illustrate the association between aggregate price shocks and financial instability, and hence the impact on financial conditions of deviating from price stability.

\section{Conclusion}

The results reported in this paper support the claim that price stability and financial stability are complementary. Certainly not all episodes of extreme financial distress or euphoria 
in U.K. history were the result of aggregate price shocks, but we find compelling evidence that such shocks often have been an important cause of financial instability.

Outside of wartime, our empirical evidence indicates that aggregate price shocks have had both a statistically significant and a large impact on financial conditions in the United Kingdom. During the gold standard era, 1821-1931, we find that deflationary shocks to the U.K. price level worsened aggregate financial distress while inflationary shocks contributed to expansionary financial conditions. And, since 1972, we find that negative shocks to the U.K. inflation rate have worsened financial distress, while the immediate effect of positive shocks has been to contribute to financial expansion. Positive shocks, of course, are no more likely to hold financial distress permanently below the equilibrium level that the interaction of private markets and extant regulatory regime would produce, any more than such shocks could hold the unemployment rate below its "natural" rate.

Our historical analysis has also highlighted how financial regimes can affect the impact of macroeconomic disturbances on the financial system. Government regulation of financial intermediation, e.g., lending limits, capital controls, etc., can limit the ability of firms and individuals to respond to market signals. Tight regulation of the financial sector, therefore, can lessen speculative financing and other forms of financial expansion that often are associated with lending booms. In doing so, they can limit the financial distress associated with unanticipated price level (or inflation) decline. For the period of heavy government regulation of the U.K. financial sector after World War II, we detect no statistically significant impact of inflation rate shocks on financial conditions. We do not necessarily advocate such controls, however, because regulation undoubtedly entails costs, perhaps including slower economic growth, and a full analysis of the costs and benefits of financial regulation are beyond the scope of this paper. A monetary policy that limits movement in the price level may be a preferable means of limiting financial instability (while possibly contributing to a higher rate of growth), but regulation can affect the extent to which aggregate price shocks cause financial instability. 


\section{Appendix A: Index Construction*}

For 1926-39, we base our index of financial conditions on annual data on household and firm bankruptcy rates (bankruptcy per capita), and on the excess return on housing (annual percentage change in an index of U.K. housing prices minus the annual market yield on consols). For each series, we compute the annual difference between each year's rate and the de-trended mean rate for 1922-39 $\left(\left(x_{t}-\bar{x}_{t}\right)\right.$ and $\left.\left(y_{t}-\bar{y}_{t}\right)\right)$, divided by the standard deviation of annual observations over that period. We multiply the standardized deviations for the bankruptcy rate series by -1 so that smaller (more negative) observations are associated with greater distress. We then compute the annual mean of the standardized distances of the two series:

$$
\Phi_{t}=0.5\left[\left(x_{t}-\bar{x}_{t}\right) / \sigma_{x}+\left(y_{t}-\bar{y}_{t}\right) / \sigma_{y}\right]
$$

For 1948-99, we base the index on the corporate insolvency rate and on excess return on housing. Data on corporate insolvencies are available only since 1960 . For prior years, we estimate insolvency rates using data on bankruptcies described above. Bankruptcy and insolvency rates are highly correlated during 1960-86. The insolvency rate is defined as the number of insolvencies divided by number of firms. The number of firms is not available for 1980-82, 1984, 1985, and 1987. Estimates for these years are interpolations fit to a spline function based on total employment, which is highly correlated with the number of firms in other years.

For 1948-49, we compute annual standardized distance measures for both series as described above for 1926-39. For 1948-99, however, we take account of changes in the volatility of each underlying series. We first compute the number of standard deviations that an index component is from its linear trend. We then estimate an $\mathrm{AR}(2)$ autoregressive model of these deviations from trend with exponential GARCH $(1,1)$ errors to estimate conditional volatility. If the conditional volatility is twice its normal level, for example, we multiply the number of standard deviations that an index component lies from its linear trend by one-half:

$$
\text { modified standardized distance }(\text { m.s.d. } y)=\left[\left(y_{t}-\bar{y}_{t}\right) /\left(\sigma_{y} \sigma_{y t} / \bar{\sigma}_{y t}\right)\right]
$$

In addition, in computing the annual mean of the standardized distances of the two series, we weight each series of distances by its relative conditional volatility, down-weighting the more volatile series. The precise weighting scheme is:

$$
\begin{aligned}
& \lambda_{t}=\left(1+\frac{\sigma_{x t}}{\bar{\sigma}_{x t}} / \frac{\sigma_{y t}}{\bar{\sigma}_{y t}}\right)^{-1} \\
& \Phi_{t}=\lambda_{t}\left(\text { m.s.d. } y_{t}\right)+\left(1-\lambda_{t}\right)\left(\text { m.s.d. } x_{t}\right)
\end{aligned}
$$

Finally, for both subperiods, we assign years in which $\Phi_{t}<-1.25$ to the "severe distress" category; years in which $-1.25<\Phi_{t}<-0.5$ to the "moderate distress" category; years in which $-0.5<\Phi_{t}<0.5$ to the "normal category; years in which $0.5<\Phi_{t}<1.25$ to the "moderate expansion" category; and years in which $\Phi_{t}>1.25$ to the "euphoria" category.

* No index is computed for 1940-47. 


\section{Appendix B: Data Sources}

Insolvency Rate: Annual number of company liquidations divided by number of firms in operation.

Company Liquidations: $\quad$ 1960-1974 - Company liquidations, England and Wales, Central Statistical Office, Economic Trends (March 1975).

1975-1999 - Total company insolvencies (England and Wales, nsa), Office of National Statistics, Financial Statistics (Table 6.1A).

Number of Firms: $\quad$ 1960-1968 - Board of Trade Journal (7 Feb. 1969)

1969-1978 - Trade and Industry (various issues)

1979-1993 - Small Business Research Trust, Andrew McCann,

"A Business Register - the way to count small businesses" (no data for 1980-82, 1984, 1985, 1987)

1994-1999 - UK Department of Trade and Industry Small and Medium Enterprise(SME) Statistics press releases.

Bankruptcy Rate: Annual number of bankruptcies per capita.

Total bankruptcies, England and Wales:

1790-1852 - Data provided by Anna Schwartz, compiled for Gayer, et. al. (1953).

1884-1944 - Mitchell (1988, pp. 695-96).

1945-1973 - Annual Abstract of Statistics (1955, 1965, 1973).

1974-1999 - Office of National Statistics, Financial Statistics

Midyear Resident Population, England and Wales:

1790-1950 - Mitchell (1998, Table A5).

1951-1999-UK Office of National Statistics, Monthly Digest of Statistics.

Country Bank Failures:

1791-1830 - Data provided by Anna Schwartz, compiled for Gayer, et. al. (1953).

Excess Return on Housing: Annual percent change in housing price index minus market yield on consols.

Housing price index:

1919-1938 - Liesner (1989, Table UK.8)

1939-1962 - Mitchell (1988, Table Prices10, pp. 739-41)

1963-1999 - Retail Price Index for Housing, Central Statistical Office

Consol yield:

1811-1962 - 3\% Consols Yield (until 1899) then 2.5\% Consols

Yield, Homer and Sylla (1991, pp. 195-97, 444-46)

1963-1999 - BGS 2.5\% Consols Gross Flat Yield, Office of National Statistics, Financial Statistics

Price level (December): December observation of the following series

1790-1844 - Index of wholesale prices of domestic and imported commodities, Gayer, et. al. (1953, p. 468)

1845-1890 - "market price" commodity index, Klovland (1993) 
1891-1947 - Sauerbeck-Statist commodity price index, NBER macroeconomic history database, www.nber.org

1948-1999 - Retail Price Index, www.statistics.gov.uk/statbase.

Price level (cost-of-living): Annual average data

1790-1959 - Mitchell (1988, Table H2)

1960-1999 - Consumer Price Index, OECD Main Economic Indicators.

Output:

1790-1829 - Hoffman Index of Industrial Production, Mitchell (1988, p. 421)

1830-1965 - Real gross domestic product, Mitchell (1998, Table $\mathrm{J} 1)$

1966-1980 - Real gross domestic product, Mitchell (1988, Table 6B)

1981-1999 - Real gross domestic product, OECD National Accounts.

Liquidity:

1790-1833 - Bank of England circulation, drawing accounts, deposits and bullion, Mitchell (1962, pp. 442-43)

1834-1870 - High-powered money, Huffman and Lothian (1980, pp. 170-71)

1871-1970 - High-powered money, Capie and Webber (1985, Table 1.1)

1971-1999 - M0, Bank of England, Statistical Abstract.

Terms of Trade (price of exports divided by price of imports):

1796-1913 - Net Barter Terms of Trade, Mitchell (1962, pp. 331-32)

1914-1969 - Net Barter Terms of Trade, Mitchell (1988, pp. 527-87)

1970-1999 - Terms of trade (overseas trade statistics basis, nsa)

Central Statistical Office, Monthly Review of External

Trade. 


\section{Appendix C: Dynamic Probit Model Estimation Details}

The Gibbs sampler and conditional distributions

The Gibbs sampler is an attractive estimation procedure for the time-series probit because the conditional distribution of the latent variable is easy to derive, given the other parameters and state variables $\left(\beta, \rho, S 1, S 2, p_{j}, q_{j}\right), j=1,2$, and the conditional distributions of the state variables are simple, given values for the latent variable and parameters. The key idea behind Gibbs sampling is that after a sufficient number of iterations, the draws from the respective conditional distributions jointly represent a draw from the joint posterior distribution, which often cannot be evaluated directly (Gelfand and Smith, 1990).

Gibbs sampling consists of iterating through cycles of draws of parameter values from conditional distributions as follows:

$$
\begin{array}{l|l}
f\left(\varsigma_{1}^{(i+1}\right. & \left.\varsigma_{2}^{(i)}, \varsigma_{3}^{(i)}, \varsigma_{4}^{(i)}, \mathrm{Y}_{T}\right) \\
f\left(\varsigma_{2}^{(i+1}\right. & \left.\varsigma_{1}^{(i+1)}, \varsigma_{3}^{(i)}, \varsigma_{4}^{(i)}, \mathrm{Y}_{T}\right) \\
f\left(\varsigma_{3}^{(i+1}\right. & \left.\varsigma_{1}^{(i+1)}, \varsigma_{2}^{(i+1)}, \varsigma_{4}^{(i)}, \mathrm{Y}_{Y}\right) \\
f\left(\varsigma_{4}^{(i+1}\right. & \left.\varsigma_{1}^{(i+1)}, \varsigma_{2}^{(i+1)}, \varsigma_{3}^{(i+1)}, \mathrm{Y}_{T}\right)
\end{array}
$$

where $\mathrm{Y}_{T}$ stands for the entire history of the data and superscript $i$ indicates run number $i$ through the Gibbs sampler. At each step, a value of $\varsigma$ is drawn from its conditional distribution. As discussed in Albert and Chib (1993), all of the necessary conditional distributions can be standard statistical distributions, given appropriate choices for prior distributions.

We ran the Gibbs sampler a total of 8000 iterations for each model specification. We discarded the first 3000 iterations to allow the sampler to converge to the posterior distribution. For this application, parameters and latent data are sampled in the following groups:

$$
\begin{aligned}
& \varsigma_{1}=\left\{y_{t}^{*}\right\}, t=1, \ldots, \mathrm{T} \text { latent variables } \\
& \varsigma_{2}=\left(\left\{S 1_{t}\right\},\left\{S 2_{t}\right\}\right), t=1, . ., \mathrm{T} \text { states } \\
& \boldsymbol{\varsigma}_{3}=(\beta, \rho) \text { regression coefficients } \\
& \boldsymbol{\varsigma}_{4}=\left(p_{j}, q_{j}\right), j=1,2 \text { transition probabilities. }
\end{aligned}
$$




\section{Gibbs sampling distributions}

We drew the Markov switching parameters in accordance with the procedures of Dueker (1999). In all cases the Markov state variables, $S 1$ and $S 2$, were treated symmetrically, so in the following description we drop references to a particular state variable.

The likelihood function for a discrete binary random variable governed by a first-order Markov process is

$$
L(p, q)=p^{n 00}(1-p)^{n 01} q^{n 11}(1-q)^{n 10}
$$

where $n_{i j}$ is the number of transitions between $S_{t-1}=i$ and $S_{t}=j$.

The prior is to assign parameters $u_{i j}$, where the ratio between $u_{00}$ and $u_{01}$, for example, represents a prior guess for the ratio between the corresponding numbers of actual transitions, $n_{00} / n_{01}$. The magnitudes of the $u_{i j}$ relative to the sample size indicate the strength of the prior. As a weak prior, we set $u_{00}=4, u_{01}=1, u_{10}=1$, and $u_{11}=4$, such that the sum of the $u_{i j}$ is low relative to the sample size.

The beta distribution is conjugate to itself, so the posterior is also beta and is the product of the prior and the likelihood of the observed transitions, so that we may draw transition probabilities from

$$
\begin{array}{l|l}
p & \widetilde{S}_{T} \sim \operatorname{beta}\left(u_{00}+n_{00}, u_{01}+n_{01}\right) \\
q & \widetilde{S}_{T} \sim \operatorname{beta}\left(u_{11}+n_{11}, u_{10}+n_{10}\right),
\end{array}
$$

where $\widetilde{S}_{T}=\left\{S_{t}\right\}, t=1, \ldots, \mathrm{T}$. We set the initial values for $p$ and $q$ at the start of the Gibbs sampling at $p=0.8$ and $q=0.6$.

\section{Priors and posteriors for Markov state variables}

We wish to sample the states in reverse order from the following probability, where $T$ stands for the entire history of the observed and latent data and $v_{t}$ is the observed and latent data at a point in time: 


$$
P\left(S_{t}=0 \mid S_{t+1}, \ldots, S_{T}, Y_{T}\right)
$$

By Bayes theorem, and as outlined in Chib (1996),

$$
\begin{aligned}
P\left(S_{t}=0 \mid S_{t+1}, \ldots, S_{T}, T_{T}\right) \propto & f\left(v_{t+1}, \ldots, v_{T}, S_{t+1}, \ldots, S_{T} \mid v_{1}, \ldots, v_{t}, S_{t}\right) \times \\
& P\left(S_{t} \mid v_{1}, \ldots, v_{t}\right) \\
\propto & f\left(v_{t+1}, \ldots, v_{t}, S_{t+2}, \ldots, S_{T} \mid v_{1}, \ldots, v_{t}, S_{t}, S_{t+1}\right) \times \\
& P\left(S_{t+1} \mid S_{t}\right) \times P\left(S_{t} \mid v_{1}, \ldots, v_{t}\right) \\
\propto & P\left(S_{t+1} \mid S_{t}\right) \times P\left(S_{t} \mid v_{1}, \ldots, v_{t}\right) .
\end{aligned}
$$

The first and second proportions in equation (B.6) are simply applications of Bayes'

theorem. Because the density $f\left(v_{t+1} \ldots, v_{T}, S_{t+2}, \ldots, S_{T} \mid v_{1}, \ldots, v_{t}, S_{t}, S_{t+1}\right)$ is independent of $S_{t}$, it can be subsumed into the constant of proportionality, which can easily be recovered in order to draw states. As shown in equation (C.6), the only necessary inputs are the transition probabilities and the filtered probabilities conditional on the contemporaneous data.

Priors and posteriors for $\beta$ coefficients

Following Albert and Chib (1993), the prior for $\beta$ is diffuse and the initial value for $\beta$ in the first cycle of the Gibbs sampler is the ordinary least square estimate from the regression of the initial draw of $y^{*}$ on the right-hand variables. Like Albert and Chib (1993, p. 671), we use a flat uninformative prior for $\beta$ because our initial draw of $y^{*}$ is uninformative. For this reason, we do not wish to allow a prior distribution around the starting OLS estimate to influence the posterior distribution.

With $\sum_{T}$ denoting the diagonal matrix with entries from the vector $\left(\sigma_{S 1_{t}}^{2}, t=1, \ldots, \mathrm{T}\right)$, the posterior distribution for $\beta$ is the multivariate normal distribution for generalized least squares coefficients:

$$
\beta \sim \mathrm{N}\left(\left(\mathrm{X}^{\prime} \sum_{T}^{-1} \mathrm{X}\right)^{-1} \mathrm{X}^{\prime} \sum_{T}^{-1} y^{*},\left(\mathrm{X}^{\prime} \sum_{T}^{-1} \mathrm{X}\right)^{-1}\right)
$$


where the matrix $X$ is understood to include the lagged dependent variable and intercept dummies for $S 2$ and $(1-S 2)$. Hence the $\beta$ coefficients described here include the autoregressive and drift coefficients.

Generating latent variables, $y_{\mathrm{t}}^{*}$

The initial values of $y_{t}^{*}, t=1, \ldots, \mathrm{T}$ are drawn from $f\left(y_{t}^{*} \mid y_{t-1}^{*}, y_{t} \in\right.$ cat. $\left.j\right)$. In this case,

$$
y_{t}^{*} \sim \mathrm{N}\left(\rho y_{t-1}^{*}+X_{t}^{\prime} \beta, \sigma_{S t}^{2}\right)
$$

with truncation such that $y_{t}^{*} \in\left(c_{j-1}, c_{j}\right)$. These expressions imply that the disturbance, $\varepsilon_{t}$, is in the interval $\left[-\rho y_{t-1}^{*}-\mathrm{X}_{t}^{\prime} \beta+c_{j-1}, \rho y_{t-1}^{*}-\mathrm{X}_{t}^{\prime} \beta+c_{j}\right)$. Denote this interval as $\left[l_{t}, u_{t}\right)$. The standardized shock, $\varepsilon_{t} / \sigma_{s t}^{2}$ is in the interval $\left[-\rho y_{t-1}^{*}-\mathrm{X}_{t}^{\prime} \beta+c_{j-1}, \rho y_{t-1}^{*}-\mathrm{X}_{t}^{\prime} \beta+c_{j}\right]$. Let $\Phi$ denote the cumulative normal density function. To sample from the truncated normal, we first draw a uniform variable, $v_{t}$, from the interval $\left[\Phi\left(l_{t} / \sigma_{1 t}\right), \Phi\left(u_{t} / \sigma_{1 t}\right)\right]$. The truncated normal draw for the standardized shock is then $\Phi^{-1}\left(v_{t}\right)$.

We take subsequent draws from

$$
f\left(y_{t}^{*(i+1)} \mid y_{t-1}^{*{ }^{(i+1)}}, y_{t+1}^{*(i)}, y_{t} \in \text { cat.j }\right),
$$

where, as in equation (C.1), superscript $i$ denotes the $i^{\text {th }}$ cycle of the Gibbs sampler. We use the density from equation (C.7), because sampling the entire vector jointly from $f\left(y_{1}^{*}, \ldots, y_{T}^{*} \mid Y_{T}\right)$ would require evaluation of a density equivalent to the cumbersome likelihood function from equation (2). To draw from (C.7), we note that unconditionally $\left(\varepsilon_{t}, \varepsilon_{t+1}\right)$ are distributed as independent, bivariate normals with mean zero:

$$
f\left(\varepsilon_{t}, \varepsilon_{t+1}\right)=\frac{1}{2 \pi \sigma_{s_{t}} \sigma_{s_{t+1}}} \exp \left\{-.5 \varepsilon_{t}^{2} / \sigma_{S_{t}}^{2}-.5 \varepsilon_{t+1}^{2} / \sigma_{S_{t+1}}^{2}\right\}
$$

Given equation (1), we can write 


$$
\begin{aligned}
y_{t+1}^{*} & =\rho y_{t}^{*}+\mathrm{X}_{t+1}^{\prime} \beta+\varepsilon_{t+1} \\
& =\rho^{2} y_{t-1}^{*}+\rho \mathrm{X}_{t}^{\prime} \beta+\rho \varepsilon_{t}+\mathrm{X}_{t+1}^{\prime} \beta+\varepsilon_{t+1} .
\end{aligned}
$$

Conditional on values for $y_{t-1}^{*}$ and $y_{t+1}^{*}$, we know the particular value, denoted $r_{0}$, of $\rho \varepsilon_{t}+\varepsilon_{t+1}$. Substitute $r_{0}-\rho \varepsilon_{t}$ for $\varepsilon_{t+1}$ in the joint density of equation (C.8) and after some algebra we find that

$$
y_{t}^{*} \sim \mathrm{N}\left(\rho y_{t-1}^{*}+\mathrm{X}_{t}^{\prime} \beta+\frac{\rho r_{0} \sigma_{S_{t}}^{2}}{\rho^{2} \sigma_{S_{t}}^{2}+\sigma_{S_{t+1}}^{2}}, \frac{\sigma_{S_{t+1}}^{2} \sigma_{S_{t}}^{2}}{\rho^{2} \sigma_{S_{t}}^{2}+\sigma_{S_{t+1}}^{2}}\right)
$$

We then draw $y_{t}^{*}$ as a truncated normal as described above.

\section{Drawing Threshold coefficients}

With five discrete categories for financial conditions, we need to draw four cut-off coefficients for the vector $c_{j}, j=0, \ldots, 4$ where $c_{0}=-\infty$ and $c_{4}=\infty$. For the discrete

variable, $y_{t}$ is in category $j$ when the latent variable $y_{t}^{*} \in\left(c_{j-1}, c_{j}\right)$. The threshold coefficients also delimit ex ante probabilities for being in a given category prior to knowing what disturbance will hit the latent variable:

$$
\begin{aligned}
& \operatorname{Prob}(\text { Euphoria })=1-\mathrm{F}\left(\left(-\mathrm{X}_{t}^{\prime} \beta+c 3\right) / \sigma_{t}\right), \\
& \operatorname{Prob}(\text { Mod.Expansion })=\mathrm{F}\left(\left(-\mathrm{X}_{t}^{\prime} \beta+c 3\right) / \sigma_{t}\right)-\mathrm{F}\left(\left(-\mathrm{X}_{t}^{\prime} \beta+c 2\right) / \sigma_{t}\right), \\
& \operatorname{Prob}(\text { Normal })=\mathrm{F}\left(\left(-\mathrm{X}_{t}^{\prime} \beta+c 2\right) / \sigma_{t}\right)-\mathrm{F}\left(\left(-\mathrm{X}_{t}^{\prime} \beta / \sigma_{t}\right),\right. \\
& \operatorname{Prob}(\text { Mod.Distress })=\mathrm{F}\left(-\mathrm{X}_{t}^{\prime} \beta / \sigma_{t}\right)-\mathrm{F}\left(\left(-\mathrm{X}_{t}^{\prime} \beta+c 1\right) / \sigma_{t}\right), \\
& \operatorname{Prob}(\text { Sev.Distress })=\mathrm{F}\left(\left(-\mathrm{X}_{t}^{\prime} \beta+c 1\right) / \sigma_{t}\right) .
\end{aligned}
$$

The relevant conditioning information for the draw of $c_{j}$ is $\left\{c_{j-1}, \mathrm{y}_{\mathrm{t}}^{*}, t=1, \ldots, \mathrm{T}\right\}$. Given this information, the posterior distribution for $c_{j}$ is uniform on the interval $\left(c_{j-1}, \min \left\{y_{t}^{*}: y_{t}^{*} \in\right.\right.$ cat. $\left.\left.j+1\right\}\right)$.

\section{Markov regime switching}

We include two forms of regime switching in the latent variable for the time-series probit. First, our model allows for heteroscedasticity by way of Markov-switching variances. 
Both the explanatory variables and the data that went into the construction of the quantitative index contain outliers that should be downweighted when estimating the regression coefficients. Therefore we introduce switching between a high and low variance level governed by a binary variable, $S 1: \sigma_{S 1_{t}}^{2} \in\left\{\sigma_{0}^{2}, \sigma_{1}^{2}\right\}$.

Second, the model includes Markov switching in the intercept, $\beta_{0}$, to allow for shifts in the unconditional level of the financial conditions index. The binary variable that governs drift switching is $S 2$ :

$$
\begin{aligned}
& y_{t}^{*}=\rho y_{t-1}^{*}+\beta_{0}\left(S 2_{t}\right)+\mathrm{X}_{t}^{\prime} \beta+\sigma_{S 1_{t}} e_{t} \\
& \beta_{0}\left(S 2_{t}\right) \in\left\{\beta_{01}, \beta_{0 h}\right\} \\
& e_{t} \sim N(0,1) \\
& \varepsilon_{t}=\sigma_{S 1_{t}} e_{t}
\end{aligned}
$$

The transition probabilities for the state variables, $S 1$ and $S 2$, are:

$$
\begin{aligned}
& \operatorname{Prob}\left(S 1_{t}=0 \mid S 1_{t-1}=0\right)=p_{1} \\
& \operatorname{Prob}\left(S 1_{t}=1 \mid S 1_{t-1}=1\right)=q_{1} \\
& \operatorname{Prob}\left(S 2_{t}=0 \mid S 2_{t-1}=0\right)=p_{2} \\
& \operatorname{Prob}\left(S 2_{t}=1 \mid S 2_{t-1}=1\right)=q_{2} .
\end{aligned}
$$

Table C.1 reports cut-off coefficient estimates, indicating the extent to which the category boundaries around the "normal" financial conditions category are symmetrical. We look for symmetry by comparing the distance between the upper bound of the "normal" category and the lower bound of the "financial euphoria" category with the distance between the lower bound of the "normal" category and the upper bound of the "severe distress" category. That is, we ask whether shocks of a given magnitude will move financial conditions from normal to either extreme, or whether a larger shock is needed in one direction. The comparison is between $0-\mathrm{c} 1$ and $\mathrm{c} 3-\mathrm{c} 2$.

For both specifications, the distance from normal to financial euphoria is greater than the distance from normal to severe distress: 28 percent greater for the December/ December price 
shocks and 18 percent greater for the annual price shocks. The cut-offs are asymmetric in this direction despite the fact that the distress region contains more observations (50) than the moderate expansion region (36). Taken by itself, one would expect the wider category to be the one that had to accommodate the greatest number of observations. We find the opposite, which suggests that financial euphoria is more elusive than severe distress.

The bottom panel of Table C.1 reports the transition probabilities for Markov switching. These probabilities sum to little more than one $(\mathrm{p}+\mathrm{q})$ in both specifications, indicating that the states are not strongly serially correlated. Episodes of high volatility are not clustered, although the low-variance state is more prevalent, as one might expect.

\section{Table C.1}

Cut-off Constants for Category Boundaries

\begin{tabular}{|l|c|c|}
\hline Model (price measure): & December/December & Annual Average \\
\hline Severe/Moderate Distress (c1) & -0.60 & -0.57 \\
Moderate Distress/Normal & Fixed at 0 & Fixed at 0 \\
Normal/Expansion (c2) & 0.76 & 0.68 \\
Expansion/Euphoria (c3) & 1.53 & 1.35 \\
\hline
\end{tabular}

Transition Probabilities for Markov Switching

\begin{tabular}{|l|r|r|}
\hline Transition Probability p1 & 0.74 & 0.73 \\
Transition Probability q1 & 0.29 & 0.30 \\
Transition Probability p2 & 0.65 & 0.65 \\
Transition Probability q2 & 0.36 & 0.36 \\
Intercept S2=0 & 0.03 & -0.04 \\
Intercept S2=1 & 0.16 & 0.09 \\
\hline
\end{tabular}

Note: The variances are fixed at 0.10 when $\mathrm{S} 1=0$ and 0.50 when $\mathrm{S} 1=1$. 


\section{References}

Albert, J. H., and Chib, S., "Bayesian Analysis of Binary and Polychotomous Response Data," Journal of the American Statistical Association 88, 1993, pp. 669-79.

Barth, James R. The Great Savings and Loan Debacle. Washington: AEI Press, 1991.

Batchelor, Roy A., "The Avoidance of Catastrophe: Two Nineteenth Century Banking Crises," in Forrest Capie and Geoffrey E. Wood, eds., Financial Crises and the World Banking System. St. Martin's Press, 1986, pp. 41-73.

Bernanke, Ben S., "Nonmonetary Effects of the Financial Crisis in the Propagation of the Great Depression, American Economic Review 73, June 1983, pp. 257-76.

and Mark Gertler, "Monetary Policy and Asset Price Volatility," Federal Reserve Bank of Kansas City Economic Review, Fourth Quarter 1999, pp. 17-51.

and ___ "Agency Costs, Net Worth, and Business Fluctuations," American Economic Review 79, March 1989, pp. 14-31.

, ___ and Simon Gilchrist, "The Financial Accelerator in a Quantitative Business Cycle Framework," Handbook of Macroeconomics 1, 1999, pp. 1341-1393.

and Harold James, "The Gold Standard, Deflation, and Financial Crisis in the Great Depression: An International Comparison," in R. Glenn Hubbard, ed. Financial Markets and Financial Crises. Chicago: University of Chicago Press, 1991.

Bordo, Michael D., Barry Eichengreen, Daniella Klingebiel, and Soledad Martinez-Periea, "Is the Crisis Problem Growing More Severe?” Economic Policy 32, 2001, pp. 51-82.

and Finn E. Kydland, "The Gold Standard as a Rule: An Essay in Exploration," Explorations in Economic History, October 1995, pp. 423-64.

and Anna J. Schwartz, "Monetary Policy Regimes and Economic Performance: The Historical Record," Handbook of Macroeconomics. North Holland, 1999.

Capie, Forrest, "Prudent and Stable (But Inefficient?): Commercial Banks in Britain, 1890-1914, in Michael D. Bordo and Richard Sylla, eds., Anglo-American Financial Systems: Institutions and Markets in the Twentieth Century. New York: Irwin Professional Publishers, 1995, pp. 41-64.

, "Structure and Performance in British Banking, 1870-1939, in P. L. Cottrell and D. E. Moggridge, eds., Money and Power: Essays in Honour of L. S. Pressnell. London: Macmillan, 1988, pp. 73-102.

and Alan Webber. A Monetary History of the United Kingdom, 1870-1982. London: George Allen and Unwin, 1985.

and Geoffrey Wood, "Price Change, Financial Stability, and the British Economy, 18701939, working paper, 2001. 
Chib, Siddhartha, "Bayes Regression with Autoregressive Errors: A Gibbs Sampling Approach," Journal of Econometrics 58, August 1993, pp. 275-94.

Choi, Sangmok, Bruce C. Smith, and Boyd, John H., "Inflation, Financial Markets, and Capital Formation," Federal Reserve Bank of St. Louis Review 78, May/June 1996, pp. 9-35.

Dow, J. C. R. The Management of the British Economy 1945-60. Cambridge: Cambridge University Press, 1964.

Dueker, Michael J., "Conditional Heteroscedasticity in Qualitative Response Models of Time Series: A Gibbs Sampling Approach to the Bank Prime Rate," Journal of Business and Economic Statistics 17, October 1999, pp. 466-72.

Eichengreen, Barry. Golden Fetters. New York: Oxford University Press, 1992.

Eichengreen, Barry, Watson, Mark W., and Richard S. Grossman, "Bank Rate Policy Under the Interwar Gold Standard,” Economic Journal 95 (1985), pp. 725-45.

Fisher, Irving, "The Debt Deflation Theory of Great Depressions," Econometrica 1, 1933, pp. 337-57.

. Booms and Depressions. New York: Adelphi, 1932.

Friedman, Milton and Schwartz, Anna J. A Monetary History of the United States, 1867-1960. Princeton: Princeton University Press, 1963.

Gayer, Arthur D., W. W. Rostow, and Anna J. Schwartz. The Growth and Fluctuation of the British Economy, 1790-1850. Oxford: Clarendon Press, 1953.

Gelfand, A. E., and Smith, A. F. M., "Sampling-Based Approaches to Calculating Marginal Densities," Journal of the American Statistical Association 85, 1990, pp. 398-409.

Homer, Sidney, and Richard Sylla. A History of Interest Rates. New Brunswick: Rutgers University Press, 1991.

Huffman, Wallace E. and James R. Lothian, "Money in the United Kingdom, 1833-80," Journal of Money, Credit, and Banking 12, May 1980, pp. 155-74.

Kaminsky, G. L. and C. M. Reinhart, "The Twin Crises: The Causes of Banking and Balance-ofPayments Problems, American Economic Review 89, June 1999, pp. 473-500.

Kindleberger, Charles P. A Financial History of Western Europe. London: George Allen and Unwin, 1984.

Klovland, Jan Tore, "Zooming in on Sauerbeck: Monthly Wholesale Prices in Britain 18451890," Explorations in Economic History 30, April 1993, pp. 195-228.

Levy-Leboyer, Maurice, "Central Banking and Foreign Trade: The Anglo-American Cycle in the 1830s," in Charles P. Kindleberger and Jean-Pierre Laffargue, eds., Financial Crises: Theory, History and Policy. Cambridge University Press, 1978, pp. 66-110. 
Liesner, Thelma. One Hundred Years of Economic Statistics. New York: The Economist Publications, 1989.

Lucas Jr., Robert E., "Some International Evidence on Output-Inflation Tradeoffs," American Economic Review, June 1973, pp. 326-34.

, "Expectations and the Neutrality of Money," Journal of Economic Theory, April 1972, pp. 103-24.

Mitchell, B. R. International Historical Statistics, Europe 1750-1993. Fourth edition. London: Macmillan, 1998.

. British Historical Statistics. Cambridge: Cambridge University Press, 1988.

. Abstract of British Historical Statistics. Cambridge: Cambridge University Press, 1962.

Neal, Larry, "The Financial Crisis of 1825 and the Restructuring of the British Financial System," Federal Reserve Bank of St. Louis Review 80, May/June 1998, pp. 53-76.

Nelson, Daniel B. "Conditional Heteroskedasticity in Asset Returns: A New Approach.” Econometrica 59, March 1991, pp. 347-70.

Schwartz, Anna J., "Comment on 'Debt-Deflation and Financial Instability: Two Historical Explorations' by Barry Eichengreen and Richard S. Grossman," in Forrest Capie and Geoffrey E. Wood, eds., Asset Prices and the Real Economy. New York: St. Martins Press, 1997, pp. 100-105.

, "Why Financial Stability Depends on Price Stability," Economic Affairs, Autumn 1995, pp. 21-25.

, "Financial Stability and the Federal Safety Net," in William S. Haraf and Rose Marie Kushneider, eds., Restructuring Banking and Financial Services in America. Washington, D. C.: American Enterprise Institute, 1988, pp. 34-62.

Sheppard, David K. The Growth and Role of U.K. Financial Institutions 1880-1962. London: Methuen and Co., 1971.

Sykes, Joseph. The Amalgamation Movement in English Banking, 1825-1924. London: P. S. King, 1926.

Temin, Peter. The Jacksonian Economy. W. W. Norton, 1969.

Thorp, Willard Long. Business Annals. New York: National Bureau of Economic Research, 1926.

Wadsworth, J. E., ed. The Banks and the Monetary System in the U.K. 1959-1971. London: Methuen and Co., 1973. 
Table 1

Annual Index of Financial Conditions for the United Kingdom

\begin{tabular}{|c|c|c|c|c|c|c|c|c|}
\hline $\begin{array}{c}\text { Severe } \\
\text { Distress }\end{array}$ & \multicolumn{2}{|c|}{ Moderate Distress } & \multicolumn{3}{|c|}{ Normal } & \multicolumn{2}{|c|}{ Moderate Expansion } & \multirow{2}{*}{$\begin{array}{c}\text { Euphoria } \\
1809\end{array}$} \\
\hline 1793 & 1799 & 1885 & 1790 & 1865 & 1933 & 1792 & 1899 & \\
\hline 1797 & 1800 & 1890 & 1791 & 1869 & 1935 & 1802 & 1906 & 1836 \\
\hline 1816 & 1803 & 1891 & 1794 & 1872 & 1937 & 1808 & 1910 & 1919 \\
\hline 1837 & 1810 & 1894 & 1795 & 1873 & 1938 & 1813 & 1912 & 1979 \\
\hline 1839 & 1811 & 1904 & 1796 & 1874 & 1948 & 1818 & 1913 & \\
\hline 1841 & 1814 & 1907 & 1798 & 1876 & 1949 & 1823 & 1915 & \\
\hline 1847 & 1815 & 1914 & 1801 & 1879 & 1950 & 1824 & 1916 & \\
\hline 1848 & 1819 & 1920 & 1804 & 1880 & 1951 & 1834 & 1917 & \\
\hline 1857 & 1825 & 1922 & 1805 & 1882 & 1953 & 1835 & 1934 & \\
\hline 1866 & 1826 & 1931 & 1806 & 1886 & 1954 & 1844 & 1936 & \\
\hline 1878 & 1829 & 1932 & 1807 & 1887 & 1955 & 1846 & 1939 & \\
\hline 1893 & 1831 & 1952 & 1812 & 1888 & 1956 & 1852 & 1957 & \\
\hline 1908 & 1838 & 1962 & 1817 & 1892 & 1959 & 1856 & 1958 & \\
\hline 1921 & 1840 & 1965 & 1820 & 1895 & 1960 & 1863 & 1973 & \\
\hline 1993 & 1842 & 1967 & 1821 & 1897 & 1961 & 1871 & 1975 & \\
\hline & 1854 & 1968 & 1822 & 1898 & 1963 & 1881 & 1980 & \\
\hline & 1855 & 1969 & 1827 & 1900 & 1964 & 1889 & 1989 & \\
\hline & 1858 & 1982 & 1828 & 1901 & 1966 & 1896 & 1998 & \\
\hline & 1867 & 1983 & 1830 & 1902 & 1970 & & & \\
\hline & 1868 & 1984 & 1832 & 1903 & 1971 & & & \\
\hline & 1870 & 1985 & 1833 & 1905 & 1972 & & & \\
\hline & 1875 & 1986 & 1843 & 1909 & 1974 & & & \\
\hline & 1877 & 1991 & 1845 & 1911 & 1976 & & & \\
\hline & 1883 & 1992 & 1849 & 1918 & 1977 & & & \\
\hline & 1884 & 1994 & 1850 & 1923 & 1978 & & & \\
\hline & & & 1851 & 1924 & 1981 & & & \\
\hline & & & 1853 & 1925 & 1987 & & & \\
\hline & & & 1859 & 1926 & 1988 & & & \\
\hline & & & 1860 & 1927 & 1990 & & & \\
\hline & & & 1861 & 1928 & 1995 & & & \\
\hline & & & 1862 & 1929 & 1997 & & & \\
\hline & & & 1864 & 1930 & 1999 & & & \\
\hline
\end{tabular}

Source: Appendix A 
Table 2

Probit Model Estimates for Alternative Price Indexes

\begin{tabular}{|c|c|c|}
\hline Price Measure: & December/December & Annual Average \\
\hline$P^{*}, 1796-1820$ & -0.06 & -0.07 \\
\hline $95 \%$ interval & $(-0.27,0.15)$ & $(-0.25,0.12)$ \\
\hline $90 \%$ interval & $(-0.24,0.11)$ & $(-0.22,0.09)$ \\
\hline$P *, 1821-1866$ & 0.36 & 0.07 \\
\hline $95 \%$ interval & $(0.18,0.54)$ & $(-0.08,0.20)$ \\
\hline $90 \%$ interval & $(0.20,0.52)$ & $(-0.06,0.18)$ \\
\hline$P *, 1867-1931$ & 0.34 & 0.17 \\
\hline $95 \%$ interval & $(0.14,0.55)$ & $(-0.03,0.37)$ \\
\hline $90 \%$ interval & $(0.17,0.51)$ & $(-0.00,0.33)$ \\
\hline$\pi^{*}, 1932-71$ & 0.11 & -0.05 \\
\hline $95 \%$ interval & $(-0.08,0.30)$ & $(-0.26,0.16)$ \\
\hline $90 \%$ interval & $(-0.05,0.26)$ & $(-0.22,0.12)$ \\
\hline$\pi^{*}, 1972-99$ & 0.47 & 0.22 \\
\hline $95 \%$ interval & $(0.19,0.75)$ & $(0.03,0.41)$ \\
\hline $90 \%$ interval & $(0.23,0.70)$ & $(0.06,0.38)$ \\
\hline$\Delta \ln \mathrm{GDP}, 1796-1829$ & 0.04 & 0.05 \\
\hline $95 \%$ interval & $(-0.03,0.11)$ & $(-0.02,0.12)$ \\
\hline $90 \%$ interval & $(-0.02,0.10)$ & $(-0.01,0.11)$ \\
\hline$\Delta \ln \mathrm{GDP}, 1830-1931$ & 0.04 & 0.04 \\
\hline $95 \%$ interval & $(0.01,0.07)$ & $(0.01,0.07)$ \\
\hline $90 \%$ interval & $(0.02,0.07)$ & $(0.02,0.07)$ \\
\hline$\Delta \ln \mathrm{GDP}, 1932-99$ & 0.03 & 0.02 \\
\hline $95 \%$ interval & $(-0.03,0.09)$ & $(-0.03,0.08)$ \\
\hline $90 \%$ interval & $(-0.02,0.08)$ & $(-0.02,0.07)$ \\
\hline$\Delta \ln$ Base, $1796-1831$ & -0.00 & 0.01 \\
\hline $95 \%$ interval & $(-0.02,0.01)$ & $(-0.01,0.02)$ \\
\hline $90 \%$ interval & $(-0.02,0.01)$ & $(-0.01,0.02)$ \\
\hline$\Delta \ln$ Base, $1832-1931$ & 0.02 & 0.04 \\
\hline $95 \%$ interval & $(-0.00,0.05)$ & $(0.02,0.06)$ \\
\hline $90 \%$ interval & $(0.00,0.04)$ & $(0.02,0.06)$ \\
\hline$\Delta \ln$ Base, $1932-1999$ & 0.01 & 0.02 \\
\hline $95 \%$ interval & $(-0.03,0.04)$ & $(-0.01,0.05)$ \\
\hline $90 \%$ interval & $(-0.02,0.04)$ & $(-0.01,0.05)$ \\
\hline$\Delta \ln$ Terms of Trade, $1796-1931$ & -0.01 & -0.01 \\
\hline $95 \%$ interval & $(-0.02,0.01)$ & $(-0.03,0.00)$ \\
\hline $90 \%$ interval & $(-0.02,0.01)$ & $(-0.00,-0.00)$ \\
\hline$\Delta \ln$ Terms of Trade, $1932-1999$ & -0.00 & -0.01 \\
\hline $95 \%$ interval & $(-0.01,0.01)$ & $(-0.03,0.08)$ \\
\hline $90 \%$ interval & $(-0.01,0.00)$ & $(-0.02,0.07)$ \\
\hline Lag Dep. Var. & 0.30 & 0.29 \\
\hline $95 \%$ interval & $(0.15,0.47)$ & $(0.12,0.46)$ \\
\hline $90 \%$ interval & $(0.18,0.44)$ & $(0.14,0.44)$ \\
\hline
\end{tabular}

The regressions also include separate intercept dummies for 1914-19 and 1940-49. 


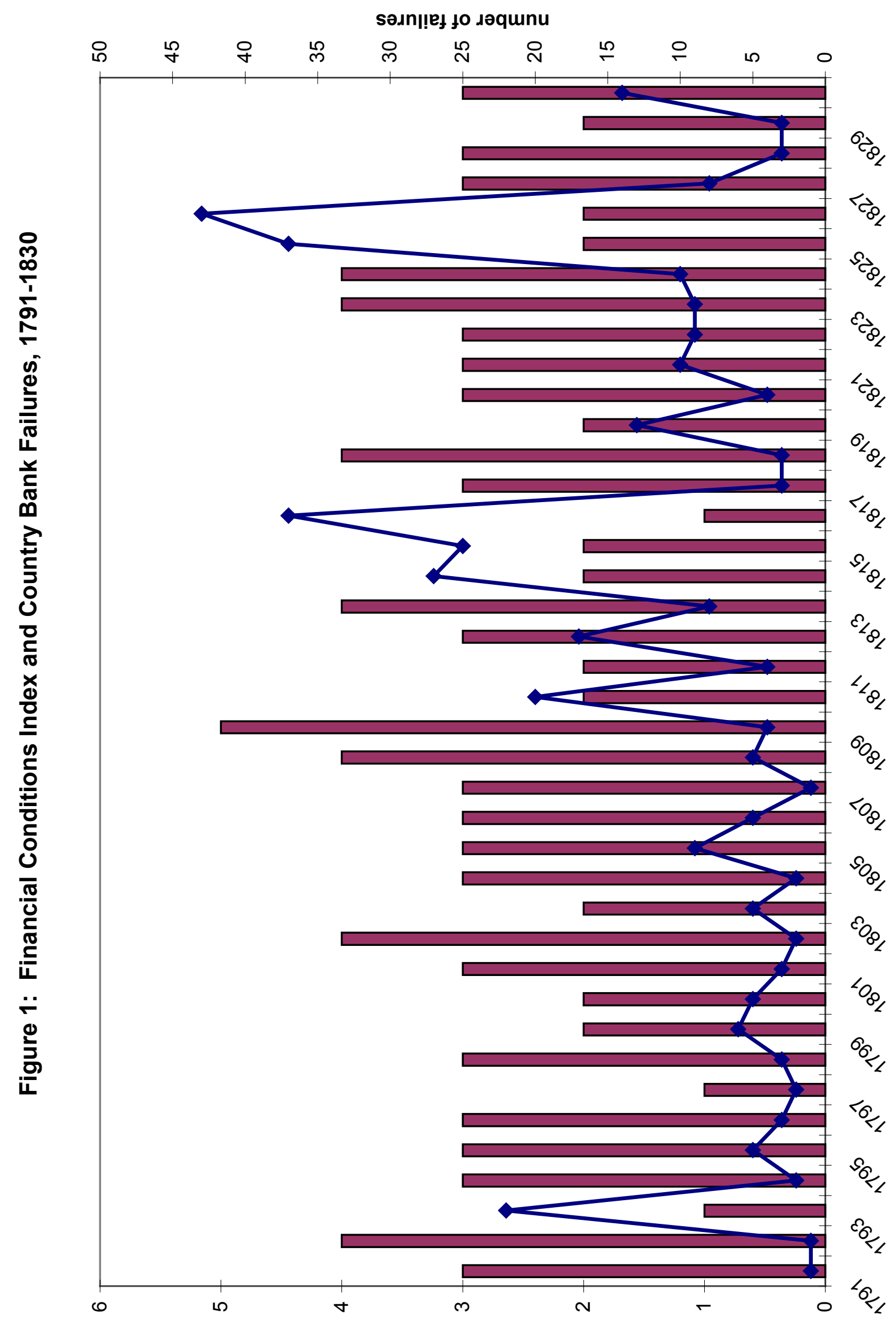




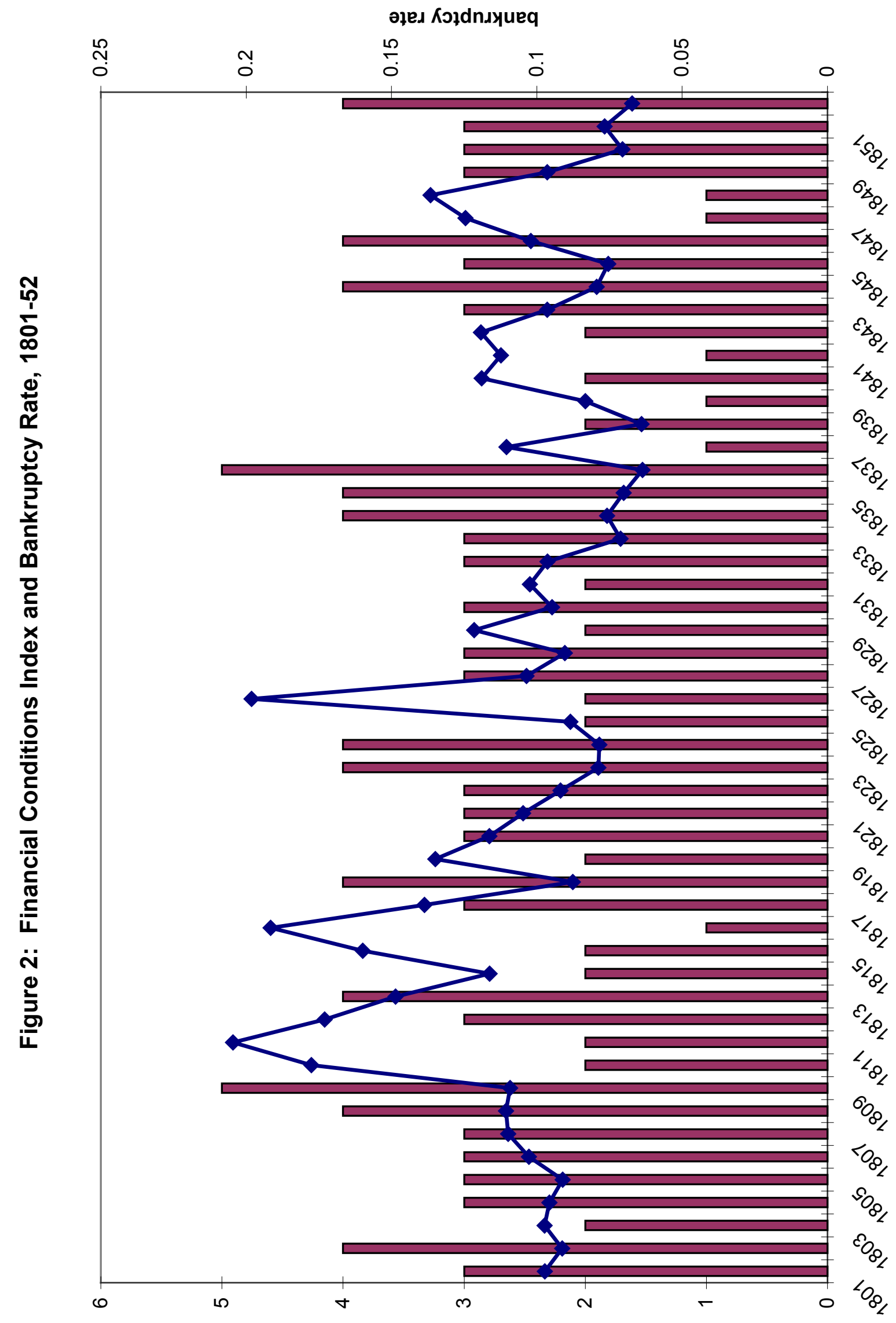




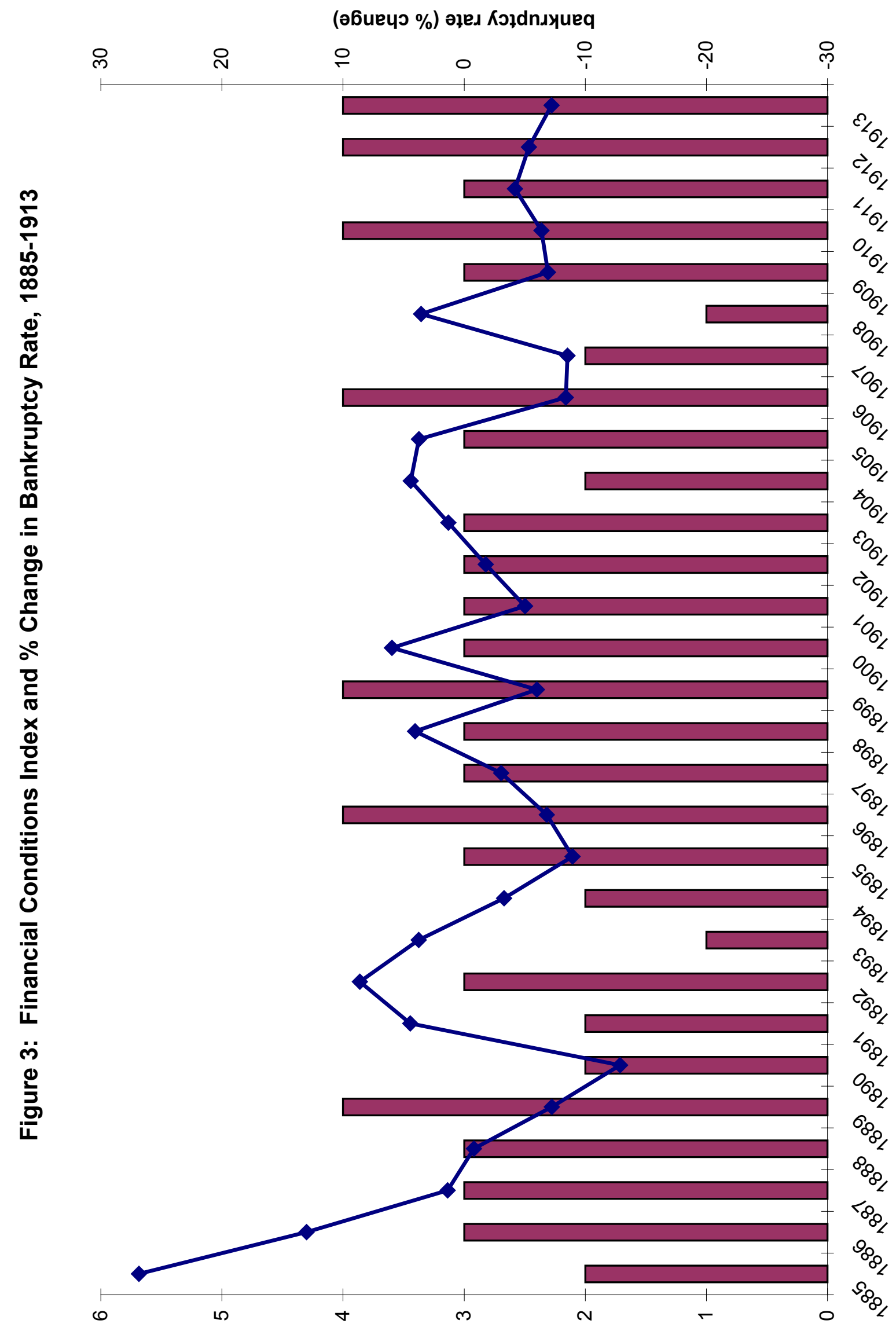




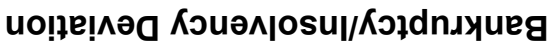

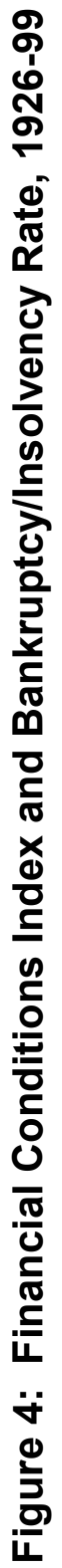

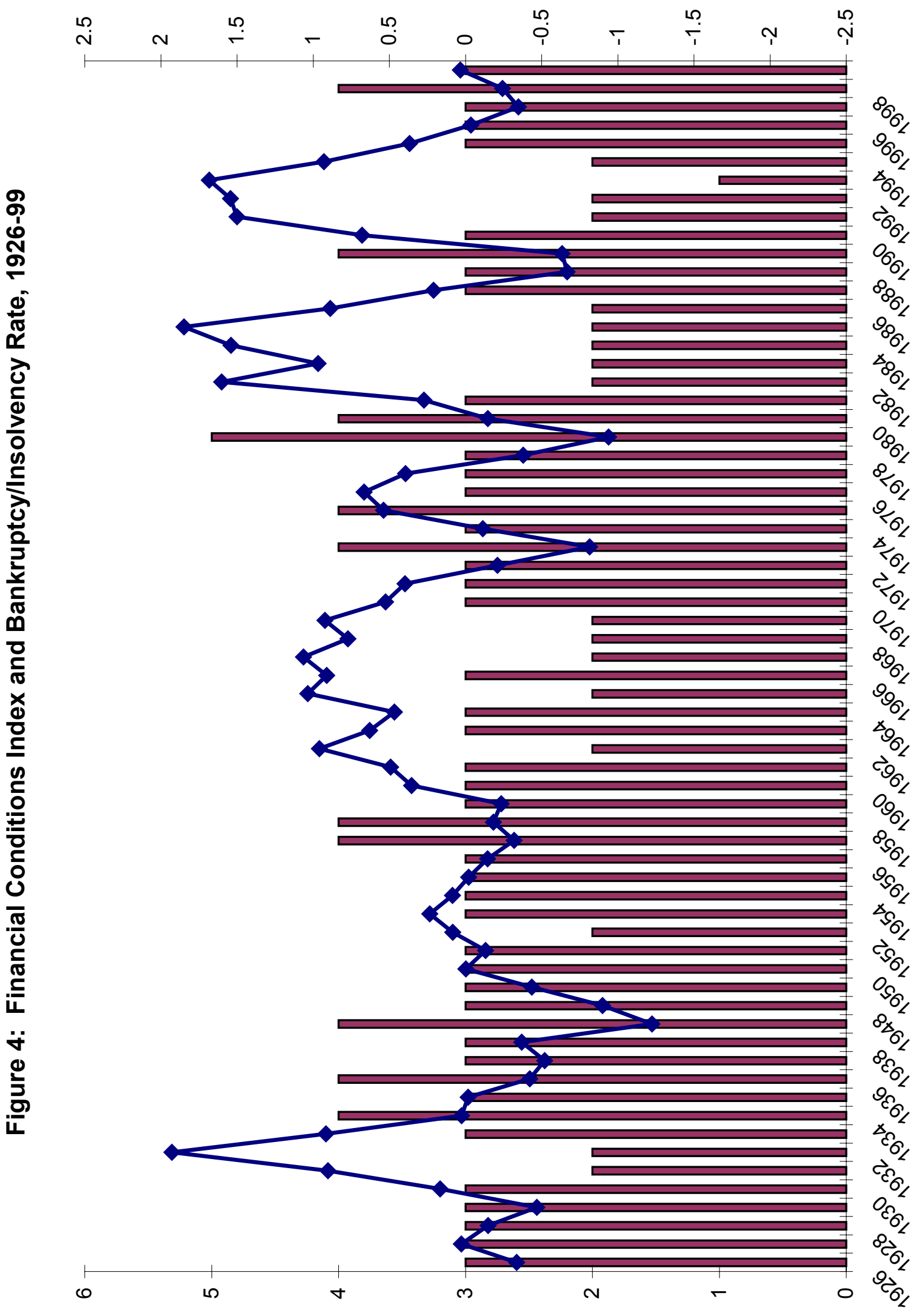

xәрu| 


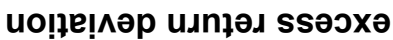

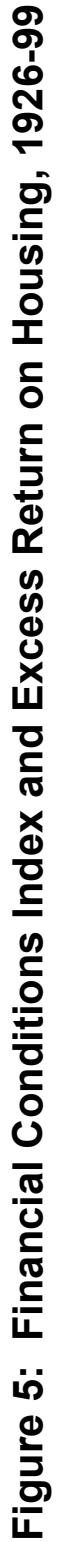

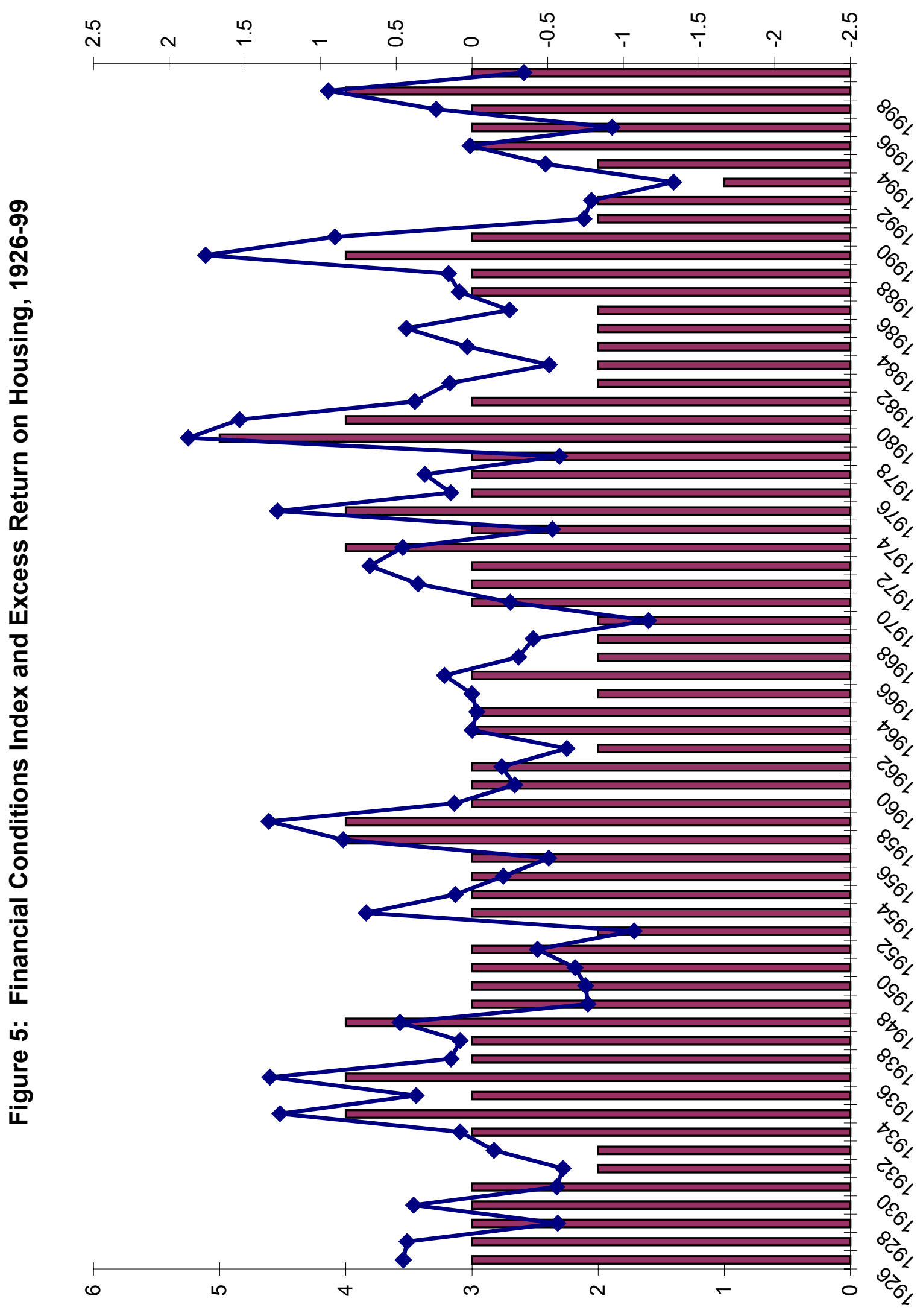

xәрu! 


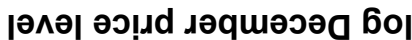

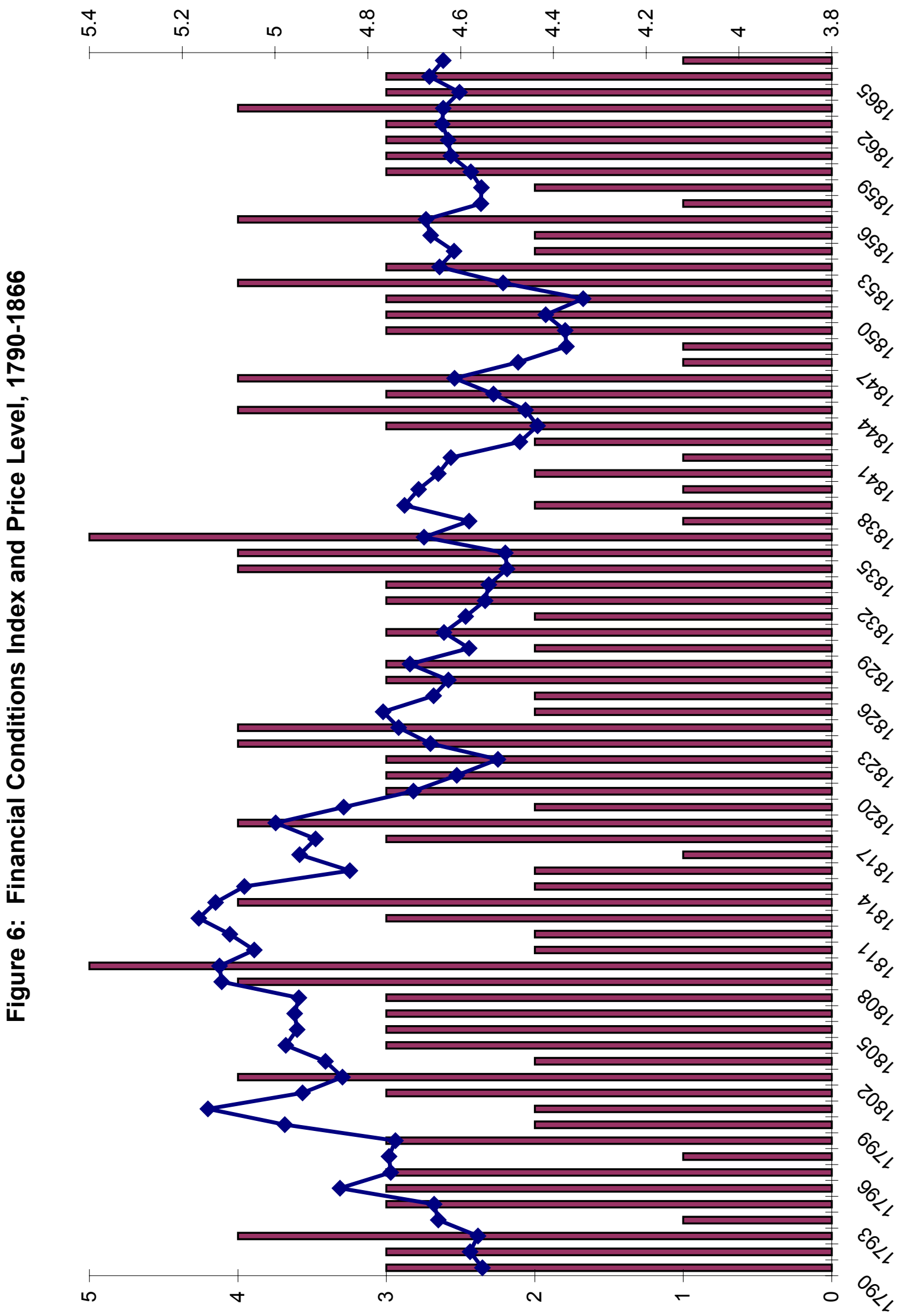




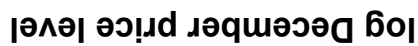

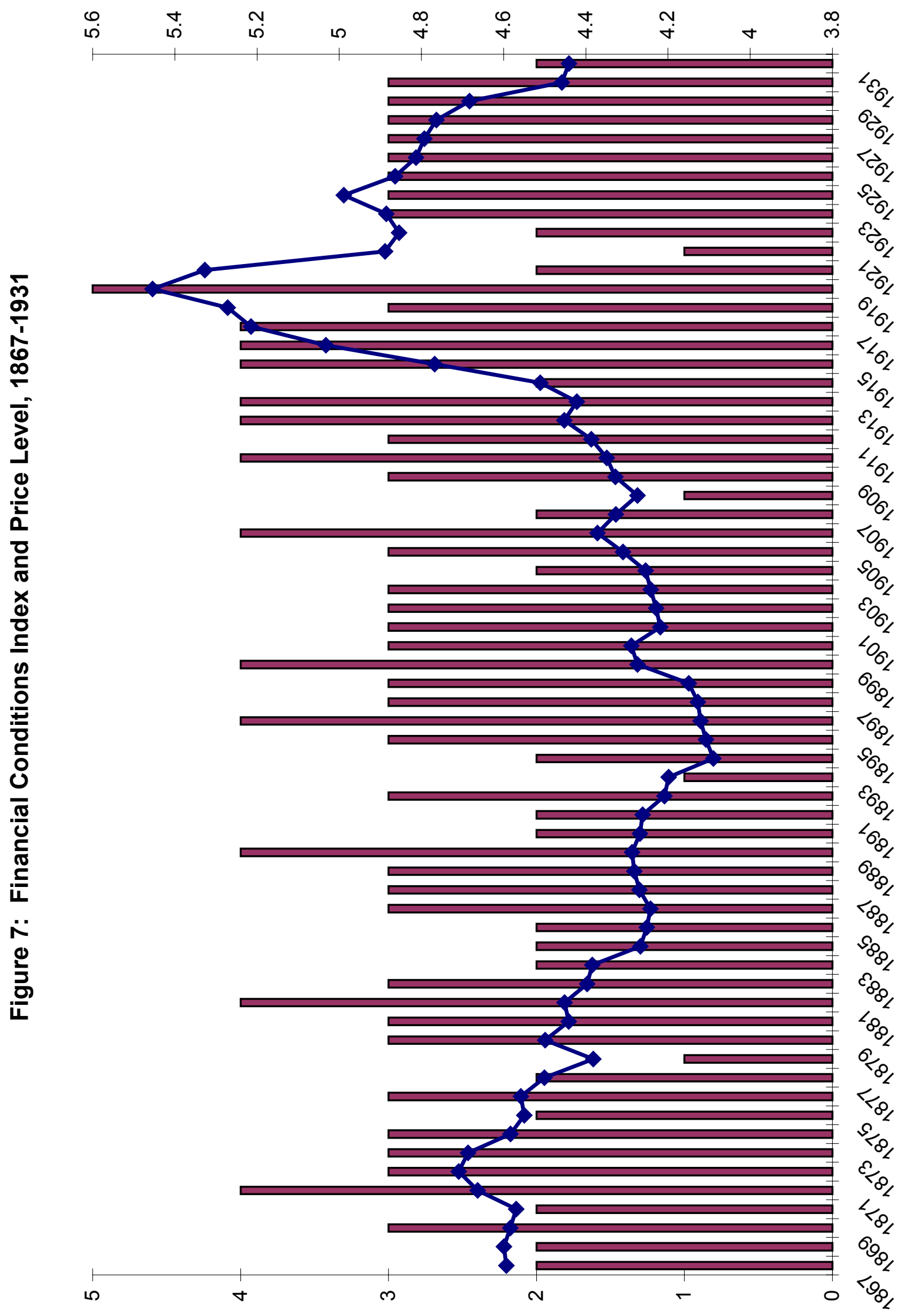


әүел ио!ฺе|яu!

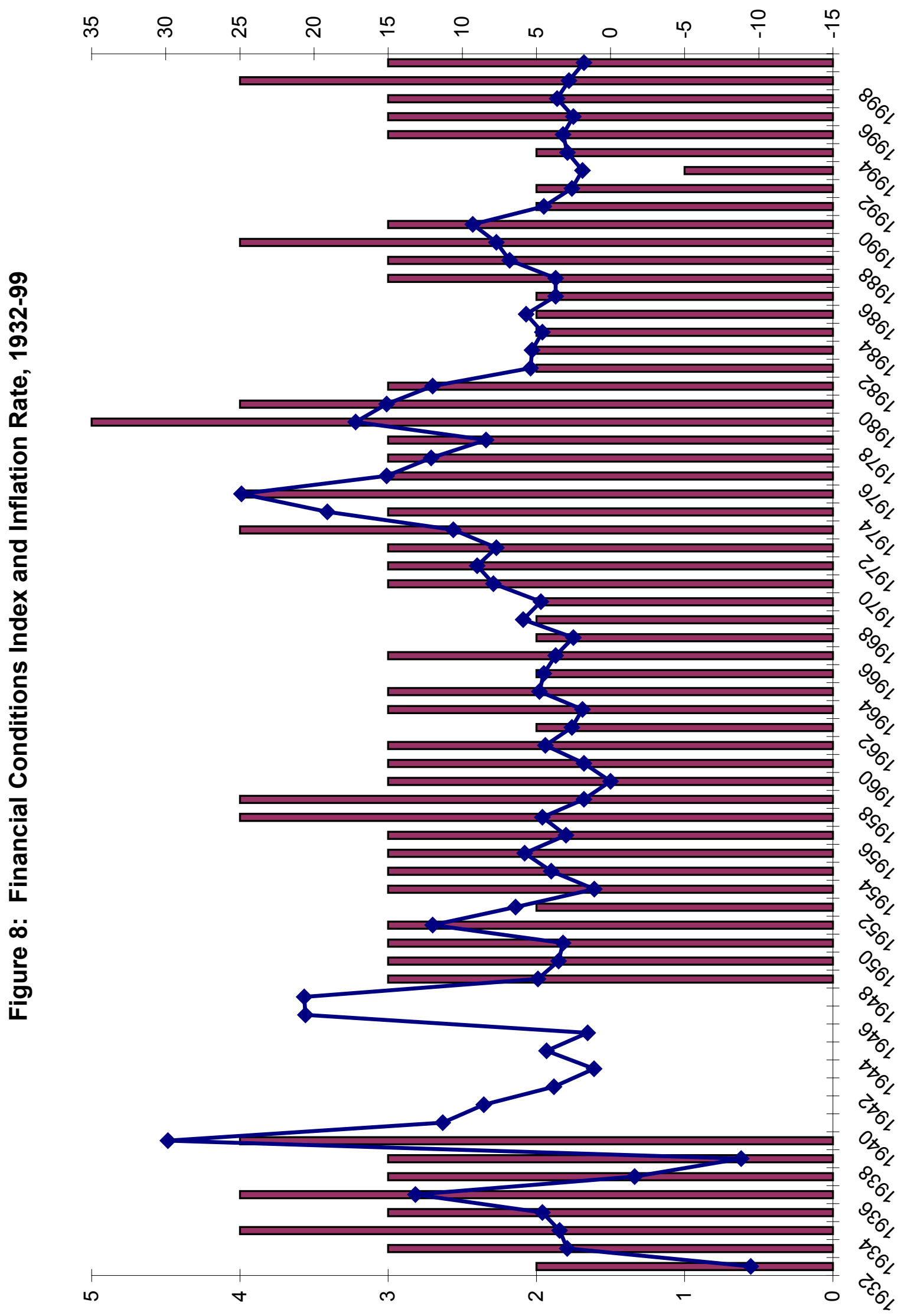


